\title{
RECENT DEVELOPMENTS IN INDIANA TAXATION SURVEY 2014
}

\author{
LAWRENCE A. JEGEN III \\ PETER PRESCOTT ${ }^{* *}$ \\ $\mathrm{JACOB}_{\mathrm{MADORE}}{ }^{* * *}$
}

\section{INTRODUCTION: SOME REFERENCES USED IN THIS ARTICLE}

This Article highlights the major tax developments that occurred during the calendar year of 2014. Whenever the term "GA" is used in this Article, the term refers only to the 118th Indiana General Assembly. Whenever the term "Tax Court" is referred to, such term refers only to the Indiana Tax Court. Whenever the term "Court of Appeals" is referred to, the term refers only to the Indiana Court of Appeals. Whenever the term "DLGF" is used, the term refers only to the Indiana Department of Local Government Finance. Whenever the term "IBTR" is used, the term refers only to the Indiana Board of Tax Review. Whenever the term "Department" or "DOR" is used, the term refers only to the Indiana Department of State Revenue. Whenever the term "Ind. Code" or "Indiana Code" is used, the term refers only to the Indiana Code, which is in effect at the time of the publication of this Article, unless otherwise explicitly stated. Whenever the term "ERA" is used, the term only refers to an Indiana Economic Revitalization Area. Whenever the term "CAGIT" is used, the term refers only to the Indiana County Adjusted Gross Income Tax. Whenever the term "COIT" is used, the term refers only to the Indiana County Option Income Tax. Whenever the term "LOIT" is used, the term refers only to the Local Option Income Tax. Whenever the term "IEDC" is used, the term refers only to the Indiana Economic Development Corporation. Whenever the term "CEDIT" is used, the term refers only to the Indiana County Economic Development Income Taxes. Whenever the term "IRC" is used, the term refers only to the Internal Revenue Code, which is in effect at the time of the publication of this Article. Whenever the term "section" is used in this Article, the term refers only to a section of the Indiana Code, unless the reference is clearly to the Internal Revenue Code. Whenever the term "Public Law" is used, the term only refers to legislation passed by the Indiana General Assembly and assigned a Public Law number. Whenever the term "PTABOA" is used, the term refers only to a Property Tax Assessment Board of Appeals.

* Thomas F. Sheehan Professor of Tax Law and Policy, Indiana University Robert H. McKinney School of Law. L.L.M., 1963, New York University; M.B.A., J.D., 1959, University of Michigan; B.A., 1956, Beloit College.

** Assistant Professor of Business Law, Butler University College of Business. J.D., 2006, University of Houston Law Center; M.P.A., 1999, University of Texas at Austin; M.S., 1993, University of Chicago; B.A., 1992, Augustana College.

*** J.D., 2015, Indiana University Robert H. McKinney School of Law; B.B.A., 2010, University of Michigan.

http://dx.doi.org/10.18060/4806.0047 


\section{INDIANA GENERAL ASSEMBLy LEGISLATION}

The 118th General Assembly passed many pieces of legislation affecting various areas of state and local taxation. Although 2014 was a short-session year, it was a relatively active one for tax legislation. This Part highlights the majority of the GA's changes from 2014 in the areas of property taxes, state gross retail and use taxes, state incomes taxes, excise taxes, and tax administration matters.

\section{A. Property Taxes}

Much of the GA's legislative activity in 2014 was directed at property taxes. While some of the results were mundane, ${ }^{1}$ the GA did make a number of important changes. The GA took steps to reduce the property tax burden arising from business personal property. ${ }^{2}$ Counties are now authorized to exempt business personal property from property taxation if the taxpayer's potentiallyexempt personal property on the assessment date has an acquisition cost of less than $\$ 20,000 .^{3}$ Certain specific types of personal property (e.g., mobile homes), and business personal property acquired by the taxpayer in non-arm's length transactions from related parties who were already using it in Indiana, do not qualify for the exemption. ${ }^{4}$ The taxpayer must file an annual certification with the county auditor claiming the exemption, ${ }^{5}$ and failure to file that certification will result in a twenty-five dollar penalty. ${ }^{6}$ Counties are also empowered to adopt an exemption ordinance that exempts all newly-acquired business personal property from property taxation. ${ }^{7}$ The exempt property must be placed in service in Indiana for the first time after the date the exemption ordinance is adopted (or after the exemption's beginning date if one is stated in that ordinance).$^{8}$ If the county amends or repeals its ordinance, all previously exempt personal property will remain exempt after the amendment or repeal. ${ }^{9}$ In addition, new business personal property that qualifies for the Deduction for Rehabilitation or Redevelopment of Real Property in Economic Revitalization Areas under a statement of benefits that was approved after June 30, 2015, may receive an

1. See, e.g., Pub. L. No. 79-2014, § 2, 2014 Ind. Acts 941, 941-42 (amending IND. CodE $\S 6-1.1-10-25$ (2014)) (removing “[a] camp of United States Spanish War Veterans" from the list of organizations whose tangible property is exempt from property taxation, presumably because there are no remaining veterans of that war to make a camp).

2. Generally, "business personal property" is personal property that is either "used in a trade or business" or is "held, used, or consumed in connection with the production of income." Pub. L. No. 80-2014, § 1, 2014 Ind. Acts 945, 945-47 (codified at IND. CoDE § 6-1.1-3-7.2 (2014)).

3. $I d$.

4. $I d$.

5. $I d$.

6. Id. $\S 7,2014$ Ind. Acts at 955-57 (amending IND. CODE $\S 6-1.1-37-7$ (2014)).

7. Id. $\S 2,2014$ Ind. Acts at 948 (codified at IND. CoDE $\S \S 6-1.1-10.3-5$ to -6 (2014)).

8. Id. $\S 2,2014$ Ind. Acts at 948 (codified at IND. CoDE $§ 6-1.1-10.3-4$ (2014)).

9. Id. $\S 2,2014$ Ind. Acts at 948-49 (codified at IND. CODE $\S 6-1.1-10.3-7$ (2014)). 
enhanced abatement schedule of up to twenty years. ${ }^{10}$

The GA also modified a number of property tax assessment dates and filing dates. Beginning in 2016, January $1 \mathrm{st}$ is the assessment date for all tangible property other than mobile homes. ${ }^{11}$ Mobile homes move to that assessment date starting in $2017 .{ }^{12}$ Furthermore, unless ordered to do so by law enacted after July 1,2014 , an assessor should not consider "change[s] in use, value, character, or ownership" that occur after the assessment date when determining the property's true tax value on the assessment date. ${ }^{13}$ For personal property taxes, the initial filing date for tax returns was set at May 15th. ${ }^{14}$ And, beginning in 2016, the assessed values on an amended personal property tax return only affect the taxes payable in the succeeding year if the taxpayer files that amended return before April 1 st. $^{15}$ Failing to meet that deadline obligates the taxpayer to pay taxes based on the assessed values shown on the original return. ${ }^{16}$

The filing date for claiming property tax exemptions was also moved forward and certain qualification procedures were updated. Starting in 2016, the exemption application due date moves from May 15 th to April 1 st. ${ }^{17}$ Similarly, the deadline for a not-for-profit corporation to inform the relevant county assessor that its property is no longer eligible for an exemption will be April 1st beginning in that year. ${ }^{18}$ When deciding whether a property is exempt, changes in the "use, value, character, or ownership" or "the age, disability, or income of any owner" that occur after the assessment date should not be considered for mobiles homes, beginning in 2017 , and for all other tangible property, beginning in 2016. ${ }^{19}$ That said, the GA now requires the property owner (or person who applied for an exemption) to notify the county assessor of a change in ownership or use of exempt property, and a change in ownership or use of exempt property after an assessment date will terminate the exemption as of that assessment date if it renders the property ineligible. ${ }^{20}$ If ownership or use changes, but exemption

10. Id. $\S 6,2014$ Ind. Acts at 954-55 (codified at IND. CODE § 6-1.1-12.1-18 (2014)). In other cases, the abatement schedule may not exceed 10 years. IND. CODE $\S 6-1.1-12.1-17$ (b) (2015).

11. Pub. L. No. 111-2014, $\S \S 1,3,2014$ Ind. Acts 1242, 1242 (codified at IND. CoDE $§ 6-1.1-$ 2-1.5 (2014) and amending IND. CODE $\S 6-1.1-1-2$ (2014)). Before 2016, the assessment date is March 1st. Id. § 3, 2014 Ind. Acts at 1242 (codified at IND. CoDE § 6-1.1-2-1.5 (2014)).

12. Id. $\S \S 1,3,2014$ Ind. Acts at 1242 (codified at IND. CODE $\S 6-1.1-2-1.5$ (2014) and amending IND. CODE $§ 6-1.1-1-2$ (2014)). Before 2016, the assessment date for mobile homes is January 15th. Id. § 3, 2014 Ind. Acts at 1242 (codified at IND. CODE $§ 6-1.1-2-1.5$ (2014)).

13. Id. $\S 4,2014$ Ind. Acts at 1243 (amending IND. CODE $\S 6-1.1-2-2(2014)$ ).

14. Id. $\S \S 2,5,2014$ Ind. Acts at 1242-43 (codified at IND. CODE $\S 6-1.1-3-1.5$ (2014) and amending IND. CODE $\S 6-1.1-1-7$ (2014)).

15. Id. $\S 6,2014$ Ind. Acts at 1243-46 (amending IND. CODE $\S 6-1.1-3-7.5$ (2014)).

16. $I d$.

17. Id. $\S 20,2014$ Ind. Acts at 1259-61 (amending IND. CODE $\S 6-1.1-11-3$ (2014)).

18. Id. $\S 21,2014$ Ind. Acts at 1261-62 (amending IND. CoDE $\S 6-1.1-11-3.5$ (2014)).

19. Id. $\S 19,2014$ Ind. Acts at 1259 (codified at IND. CODE $\S 6-1.1-11-1.5$ (2014)).

20. Pub. L. No. 183-2014, § 6, 2014 Ind. Acts 2313, 2317-20 (amending IND. CodE $§ 6-1.1-$ 
eligibility is unaffected, the exemption remains in place for the year; however, the new owner (or exemption applicant) must reapply for the exemption in the following year. ${ }^{21}$ If the county assessor discovers an ownership or use change prior to receiving the required notice, the assessor must notify the person entitled to receive the tax statement and suspend the exemption until receiving an affidavit covering whether the property remains exempt or not. ${ }^{22}$

The GA also adjusted the filing dates for a number of property tax deductions to allow taxpayers a short extension. Going forward, statements claiming the following deductions for a calendar year must be signed and dated by the taxpayer in the preceding calendar year, but they may be filed with the county assessor up through January 5th of the deduction year: the deduction for persons sixty-five or older; the deduction for blindness or disability; the deduction for surviving spouses of veterans; the deduction for partially or totally disabled veterans; the deduction for World War I veterans; the deduction for a solar energy heating or cooling system, or for solar power devices; the deduction for wind power devices; the deduction for coal conversion systems, hydroelectric power devices, geothermal energy heating or cooling devices, or use of coal combustion products; the deduction for an increase in assessed property value resulting from improvements made to comply with the fertilizer storage rules and pesticide storage rules adopted by the state chemist; the deduction for a model residence; and the deduction for residences in inventory. ${ }^{23}$ More broadly, the GA removed statutory language that caused a taxpayer to forfeit a deduction that had been approved for an assessment date, simply because the property was subsequently sold (or placed under a contract for sale) after that assessment date to a person who was ineligible for the deduction on the succeeding assessment date. ${ }^{24}$ Finally, taxpayers must now file a petition to correct an error in the tax duplicate (e.g., the assessment was against the wrong person, the tax or penalty calculation was wrong due to a math error, etc.) with the county auditor within the three-year period after the taxes were first due, or be denied relief for taxes resulting from that error. ${ }^{25}$

Ethical and professional responsibility issues in the property tax area also received attention in 2014. In addition to prohibiting the rather obvious conflictof-interest situation where a county appraiser or an employee of the county assessor serves on the county's PTABOA, ${ }^{26}$ the GA installed Standards of

$11-4(2014))$.

21. Id.

22. Id.

23. Id. $\S \S 7-15,17-18,2014$ Ind. Acts at 2320-32 (amending IND. CODE $\S \S 6-1.1-12-10.1$, $-12-12,-12-15,-12-17,-12-17.5,-12-27.1,-12-30,-12-35.5,-12-38,-12.6-3,-12.8-4$ (2014)).

24. Id. § 16, 2014 Ind. Acts at 2329-30 (amending IND. CODE § 6-1.1-12-45 (2014)).

25. Id. § 19, 2014 Ind. Acts at 2332-34 (amending IND. CODE § 6-1.1-15-12 (2014)).

26. Pub. L. No. 134-2014, § 3, 2014 Ind. Acts 1537, 1544-46 (amending IND. CodE § 6-1.128-1 (2014)); see also Pub. L. No. 112-2014, § 1, 2014 Ind. Acts 1268, 1268-71 (amending IND. CODE $\S 6-1.1-28-1$ (2014)) (making an identical change to the section). 
Conduct for assessors, appraisers, and tax representatives. ${ }^{27}$ Assessors, the assessor's employees, and appraisers working for a township or county must be competent to perform a particular assessment or, if they are not, contract with someone who is competent to perform the work. ${ }^{28}$ They must also adhere to the Uniform Standards of Professional Appraisal Practice. ${ }^{29}$ In addition, they may not engage in various inappropriate activities, including criminal conduct, making misleading or fraudulent communications, committing gross negligence, and exhibiting bias while performing an assessment. ${ }^{30}$ The DLGF may revoke the certificate of a township or county assessor, the assessor's employees, or an appraiser for gross incompetence ${ }^{31}$ subject to appeal to the certification appeal board. $^{32}$ The DLGF may also revoke a certificate for up to three years when the assessor or appraiser violates the rules contained in new chapter 6-1.1-35.7 (Assessor, Appraiser, and Tax Representative Standards of Conduct). ${ }^{33}$

Under the new professional responsibility rules, a tax representative is anyone who represents another at a proceeding before the PTABOA or the DLGF, other than (1) the property owner or its full-time employees, (2) a local government representative, (3) a certified public accountant, or (4) an attorney licensed to practice in Indiana (or with other permission to do so). ${ }^{34}$ The tax representative may not knowingly submit false or erroneous information, knowingly misrepresent any information, prepare unauthorized statements, or fail to inform the client about developments. ${ }^{35}$ The DLGF may revoke a tax representative's certification for various improper acts, including engaging in fraud or material deception, gross incompetence, or violations of the DLGF's standards of ethics. ${ }^{36}$

Tax sales were the last major property tax focus in $2014 .{ }^{37}$ First, the GA took

27. Pub. L. No. 134-2014, $\S 4,2014$ Ind. Acts at 1546-50 (codified at IND. CoDE $\S$ 6-1.1-35.7 (2014)); see also Pub. L. No. 112-2014, § 2, 2014 Ind. Acts at 1271-75 (codified at IND. CoDE § 6-1.1-35.7 (2014)) (creating an identical chapter).

28. Pub. L. No. 134-2014, § 4, 2014 Ind. Acts at 1548 (codified at IND. CoDE § 6-1.1-35.74(a) (2014)).

29. Id. $\S 4,2014$ Ind. Acts at 1547 (codified at IND. CoDE § 6-1.1-35.7-3(a) (2014)).

30. Id. $\S 4,2014$ Ind. Acts at 1547-48 (codified at IND. CODE § 6-1.1-35.7-3(b) (2014)).

31. Id. $\S 4,2014$ Ind. Acts at 1548 (codified at IND. CODE $§ 6-1.1-35.7-4$ (b) (2014)).

32. Id. $\S 4,2014$ Ind. Acts at 1548 (codified at IND. CODE $§ 6-1.1-35.7-4$ (c) (2014)).

33. Id. $\S 4,2014$ Ind. Acts at 1549 (codified at IND. CODE § 6-1.1-35.7-5(a) (2014)). New section 6-1.1-35.7-3(b) lists a number of activities that are prohibited under the new chapter, including "communicat[ing] assessment results with the intent to mislead or defraud" or "advocate[ing] for an assessment." Id. § 4, 2014 Ind. Acts at 1548 (codified at IND. CoDE § 6-1.135.7-3(b) (2014)).

34. Id. § 4, 2014 Ind. Acts at 1546-47 (codified at IND. CODE § 6-1.1-35.7-2 (2014)).

35. Id. $\S 4,2014$ Ind. Acts at 1549-50 (codified at IND. CODE $§ 6-1.1-35.7-6$ (2014)).

36. Id. $\S 4,2014$ Ind. Acts at 1550 (codified at IND. CODE § 6-1.1-35.7-7 (2014)).

37. Some of these tax sale revisions were fairly minor, or narrow, and will not be discussed in detail here. See, e.g., Pub. L. No. 166-2014, § 7, 2014 Ind. Acts 1967, 1980-81 (amending IND. CODE $\S 6-1.1-24-1$ (2014)) (clarifying that penalties, fees, and interest are included when 
steps to regulate participation in tax sales by prohibiting foreign business associations (or their agents) from purchasing property in a tax sale unless the purchasing association has obtained a certificate of authority from the Indiana Secretary of State and is in good standing in Indiana. ${ }^{38}$ Although a nonqualifying foreign business association may still purchase its own property at a tax sale, any other purchase by such an association is subject to forfeiture if the county treasurer discovers the error within six months of the sale and the association fails to correct the problem within thirty days of receiving a notice of imminent forfeiture from the county treasurer. ${ }^{39}$ However, the county treasurer may decline to forfeit the sale if circumstances suggest that the purchaser did not intend to violate the law. ${ }^{40}$ To decrease the likelihood of such a mistake, any business entity wanting to bid at a tax sale must submit a certificate of good standing or authority from the Indiana Secretary of State to the county treasurer before doing so. ${ }^{41}$

The GA also empowered each county to collect a paddle fee from those who wish to bid in tax sales in that county. ${ }^{42}$ The maximum annual paddle fee is twenty-five dollars for a person who bids in only one tax sale and buys (at most) one property. ${ }^{43}$ The maximum paddle fee is $\$ 100$ for a person who bids in more than one tax sale or buys more than one property during the year. ${ }^{44}$ The latter fee entitles the purchaser to participate in all tax sales within the county during the year. ${ }^{45}$ The paddle fees collected must be used to defer tax sale expenses or to reduce the number of vacant or abandoned houses. ${ }^{46}$

The procedures for auctioning vacant or abandoned property were also revised. Now, the county executive must obtain a court order that the property is vacant or abandoned before putting it on the list of such properties that goes to the county auditor. ${ }^{47}$ The county auditor's new statutory duties now include (1) providing public notice of the properties on the list, (2) auctioning those properties, and (3) issuing a real property deed to the highest bidder, provided

calculating the property's delinquent amount to determine whether the twenty-five dollar minimum needed for its inclusion on the list of delinquent properties is met); id. $\S 8,2014$ Ind. Acts at 198182 (amending IND. CODE $§ 6-1.1-24-1.2$ (2014)) (allowing a taxpayer to avoid having the property immediately place on the list of properties eligible for sale at a tax sale, even though the taxpayer failed to make a required payment under an earlier arrangement, if the taxpayer enters into a new property tax payment arrangement with the county treasurer).

38. Pub L. 66-2014, § 10, 2014 Ind. Acts 751, 761-63 (codified at IND. CoDE § 6-1.1-24-5.4 (2014)).

39. Id.

40. Id.

41. Id. $\S 9,2014$ Ind. Acts at 761 (codified at IND. CODE $\S 6-1.1-24-5.1$ (2014)).

42. Id. $\S 11,2014$ Ind. Acts at 763 (codified at IND. CODE $\S 6-1.1-24-16$ (2014)).

43. $I d$.

44. Id.

45. $I d$.

46. $I d$.

47. Id. $\S 6,2014$ Ind. Acts at 754-56 (amending IND. CODE $\S 6-1.1-24-1.5$ (2014)). 
that the minimum bid threshold is met (i.e., the bid covers the property's proportionate share of the costs of conducting the sale). ${ }^{48}$ Tax sale proceeds go to the county auditor to cover the costs of sale; then to the relevant county, city, or town to cover its costs of certifying as vacant or abandoned; and finally to other taxing units. ${ }^{49}$

The GA also made a number of changes affecting the property owner's postsale redemption rights and the procedures for issuing a tax deed to the tax-sale purchaser. The most dramatic change was the complete elimination of the 120day post-sale redemption period for vacant or abandoned property. ${ }^{50}$ Instead, a notice of intention to certify a parcel of real property as vacant or abandoned must be sent to the last known address of the property owner, and to anyone else with a substantial property interest that is listed in the real property records, at least 120 days before the property is certified as vacant or abandoned. ${ }^{51}$ With respect to other tax sale properties, the required time period for the tax-sale purchaser (or in some cases the county auditor) to provide notice of the tax sale to the owner of record at the time of the tax sale dropped from nine months to six months. ${ }^{52}$ Also, the time period for filing a verified petition requesting that a court direct a county auditor to issue a tax deed covering the real property purchased in a tax sale, and not redeemed, dropped from six months after the expiration of the redemption period to just three months. ${ }^{53}$ The court may now issue that deed even though there are still unpaid penalties due on the property, if those penalties did not become due until after the tax sale occurred. ${ }^{54}$ The county auditor must remove those unpaid penalties from the tax duplicate when the deed is issued to the purchaser. ${ }^{55}$ Upon issuance of the tax deed, the county auditor is obligated to (1) provide a copy of the tax deed to the grantee (i.e., the tax-sale purchaser), (2) collect the filing fees from the grantee, and (3) file the tax deed with the county recorder, who then issues a recorded tax deed to the grantee. ${ }^{56}$

Changes were made to the amount that the tax-sale purchaser is entitled to receive if the property owner redeems the property, or the tax sale is later found to be invalid. For tax sales occurring after July 1, 2014, the annual interest rate applied by the redeeming owner to the "amount by which the purchase price exceeds the minimum bid on the real property" dropped from ten percent to five

\section{Id.}

49. Id.

50. Id. $\S 13,2014$ Ind. Acts at 765-68 (amending IND. CODE § 6-1.1-24-4 (2014)).

51. Id. $\S 8,2014$ Ind. Acts at 760-61 (amending IND. CoDE $\S 6-1.1-24-2.3$ (2014)).

52. Id. $\S 14,2014$ Ind. Acts at 768-71 (amending IND. CODE $\S 6-1.1-24-4.5$ (2014)). Without this required notice, the tax-sale purchaser is not entitled to a tax deed for the property. IND. CODE $\S 6-1.1-24-4.5$ (a) (2014).

53. Pub. L. No. 66-2014, § 15, 2014 Ind. Acts at 771-74 (amending IND. CODE $§ 6-1.1-24-4.6$ (2014)).

54. Id.

55. Id. $\S 13,2014$ Ind. Acts at 765-68 (amending IND. CODE $\S 6-1.1-24-4$ (2014)).

56. Id. $\S 18,2014$ Ind. Acts at 776 (amending IND. CODE $§ 6-1.1-25-20$ (2014)). 
percent. ${ }^{57}$ Similarly, the annual interest rate applied by that owner to the amount paid by the tax-sale purchaser for taxes and special assessments after the date of sale dropped from ten percent to five percent for those post-July 1, 2014 tax sales. ${ }^{58}$ In cases where a tax sale, or a court order requiring the issuance of a certificate of sale, is found to be invalid, the county auditor must pay five percent annual interest on amounts due to the tax-sale purchaser because of that invalidation. ${ }^{59}$

Finally, the GA made relatively minor adjustments to a number of unrelated areas. ${ }^{60}$ To begin with, the transition to using new soil productivity factors when assessing the true tax value of agricultural land, which was a significant legislative event last session, was delayed for 2014 to $2015 .^{61}$ The GA also created a new $100 \%$ property tax deduction for "heritage barns." 62 A county fiscal body may adopt an ordinance requiring the heritage barn's owner to pay an annual public safety fee of up to fifty dollars. ${ }^{63}$ Another change involved property used for educational purposes by a for-profit provider of early childhood education services to four and five year old children. ${ }^{64}$ Such property is entitled

57. Id. $\S 12,2014$ Ind. Acts at 763-65 (amending IND. CODE $§ 6-1.1-25-2$ (2014)) (lowering the interest rate from ten percent to five percent); Pub. L. No. 94-2014, § 1, 2014 Ind. Acts 1054, 1054-55 (amending IND. CODE $\S 6-1.1-25-2$ (2014)) (preserving the ten percent interest rate for redemptions resulting from tax sales occurring before July 1, 2014).

58. Pub. L. No. 94-2014, § 1, 2014 Ind. Acts at 1054-55 (amending IND. CoDE § 6-1.1-25-2 (2014)). These lower rates must be reflected in the county auditor's notice of tax sale for sales occurring after June 30, 2014. Pub. L. No. 66-2014, § 7, 2014 Ind. Acts at 756-60 (amending IND. CODE $§ 6-1.1-24-2(2014))$.

59. Pub. L. No. 66-2014, $\S \S 16-17,2014$ Ind. Acts at 774-76 (amending IND. CoDE $\S \S 6-1.1-$ 25-10, -11 (2014)).

60. The specific changes discussed in these paragraphs are just a sampling of the GA's unrelated minor adjustments. See, e.g., Pub. L. No. 53-2014, § 71, 2014 Ind. Acts 408, 448 (repealing IND. CODE $§ 6-1.1-12.1-11$ (2014)) (discontinuing the previously-required quadrennial fiscal analysis of the effectiveness of property tax deductions for the redevelopment of real property in economic revitalization areas); Pub. L. No. 80-2014, § 4, 2014 Ind. Acts 945, 953-54 (codified at IND. CODE $\S 6-1.1-12.1-12.5$ (2014)) (dividing a taxpayer's repayment, reimbursement, and penalty from failing to comply with the requirements for claiming a Deduction for Rehabilitation or Redevelopment of Real Property in Economic Revitalization Areas among the taxing units containing the relevant property).

61. Pub. L. No. 85-2014, § 1, 2014 Ind. Acts 988, 988-89 (amending IND. CoDE § 6-1.1-4-13 (2014)); see also Lawrence A. Jegen III et al., Recent Developments in Indiana Taxation Survey 2013, 47 IND. L. REV. 1173, 1174-75 (2014) (discussing the GA's legislative activity in 2013 that required the transition to happen in 2014).

62. Pub. L. No. 117-2014, § 4, 2014 Ind. Acts 1380, 1381-83 (codified at IND. CoDE $§ 6-1.1-$ 12.1-26.2 (2014)). A "heritage barn" is a barn built before 1950 that is not being used for agricultural purposes (or any other business purpose) and is still structurally sound. Id.

63. Id.

64. See Pub. L. No. 151-2014, § 1, 2014 Ind. Acts 1783, 1783-88 (amending IND. CoDE $\S$ 6-1.1-10-36.3 (2014)). 
to a property tax exemption, ${ }^{65}$ without proration when the property is also used for ineligible purposes ${ }^{66}$ provided that the provider's primary purpose is educational, the property is predominately used for providing the exempt services, and the provider achieves a suitable quality rating while participating in the state's early education evaluation program. ${ }^{67}$ If the provider also provides educational services to children under four years of age, the exemption amount is reduced in proportion to the provider's enrollment counts. ${ }^{68}$

The GA extended the homestead exemption to include previously qualified property owned by an active-duty member of the United States armed forces who is ordered to transfer to a location outside of Indiana. ${ }^{69}$ The extended exemption continues to apply until the property is sold or transferred by the individual, the individual ceases to be on active duty, or the individual leases the property to another ${ }^{70}$ Finally, public utilities companies ("PUCs") face a few property tax changes. The DLGF is no longer permitted to grant a PUC an extension for filing its required statement describing, and valuing, its property. ${ }^{71}$ Instead, the PUC may file an amended statement within sixty days of filing that original statement. $^{72}$ A PUC that fails to file on time is subject to late filing penalty that cannot exceed $\$ 1000 .^{73}$ If the DLGF is forced to assess the value of its property because the PUC failed to file the required statement, the PUC is now permitted to submit a statement to the DLGF within one year after that assessment, and the DLGF may amend its assessment in reliance on the PUC's late statement. ${ }^{74}$

\section{B. State Gross Retail and Use Taxes}

The state gross retail and use tax area was fairly quiet during 2014. Many of the changes dealt with relatively minor administrative matters, ${ }^{75}$ or were technical corrections made necessary by statutory changes in the preceding

65. Id.

66. Id.

67. Id. $\S 3,2014$ Ind. Acts at 1789-90 (codified at IND. CoDE $\S 6-1.1-10-46$ (2014)).

68. Id.

69. Pub. L. No. 166-2014, § 2, 2014 Ind. Acts 1967, 1968-77 (amending IND. CoDE § 6-1.112-37 (2014)).

70. $I d$.

71. Pub. L. No. 183-2014, § 3, 2014 Ind. Acts 2313, 2316 (amending IND. CoDE § 6-1.1-8-19 (2014)).

72. Id.

73. Id. $\S 4,2014$ Ind. Acts at 2316-17 (amending IND. CODE $\S 6-1.1-8-20$ (2014)).

74. Id. $\S 5,2014$ Ind. Acts at 2317 (amending IND. CODE $\S 6-1.1-8-22$ (2014)). This procedure also applies when the DLGF has assessed the PUC's property values because the PUC did not permit the DLGF to examine its records or did not comply with a DLGF summons. Id.

75. Pub. L. No. 87-2014, § 1, 2014 Ind. Acts 992, 992 (amending IND. CoDE § 6-2.5-2-2 (2014)) (permitting a seller "to round the tax . . on a transaction on an item basis or an invoice basis," so long as the adopted rounding approach does not "circumvent the tax that would otherwise be imposed on a transaction using an invoice basis"). 
legislative session. ${ }^{76}$ However, there were several substantive changes. For example, to help improve the competitiveness of Indiana auto dealerships located near the state's borders, the GA set the state gross retail tax rate applicable to motor vehicles that are purchased in Indiana at the sales tax rate of another state or country when the purchaser intends to transport the vehicle to a destination outside of Indiana within thirty days and to title the vehicle or register it for use in that state or country. ${ }^{77}$ The GA also created a one-time credit against the state gross retail or use tax for retail merchants who sold bulk propane at retail in Indiana after December 31, 2013 and before April 1, 2014. ${ }^{78}$ The short-lived credit equals the excess state gross retail tax collected by the merchant during that period from the retail sale of bulk propane over the state gross retail tax that would have been collected during the same period on those sales if the tax had been $\$ 2.50$ per gallon. ${ }^{79}$ Although the retail merchant must pass the credit along to each effected customers as a credit against the amount due on that customer's next purchase of bulk propane from the merchant, the merchant may deduct and retain an additional collection allowance equal to one percent of the credit amount to compensate the merchant for administering the credit. ${ }^{80}$

The GA also tweaked three statutory provisions that received greater attention last year. ${ }^{81}$ The existing state gross retail tax exemption for sales of tangible personal property in connection with "the repair, maintenance, refurbishment, remodeling, or remanufacturing of an aircraft or an avionics system of an aircraft" now extends to situations where the retail merchant (1) leases a maintenance facility at a public use airport, (2) meets the airport owner's minimum standards for an airport maintenance facility, and (3) employs a Federal Aviation Administration-certified mechanic to perform the maintenance work. ${ }^{82}$ In addition, the state gross retail tax exemption for blood glucose monitoring supplies and blood glucose meters only applies when those items are provided without charge and, in the case of blood glucose meters, only when provided by a person who primarily sells the meters for resale (i.e., a non-retail seller). ${ }^{83}$ In a housekeeping measure that was necessary to comport with other revision to the

76. See, e.g., Pub. L. No. 2-2014, § 29, 2014 Ind. Acts 3, 60-61 (amending IND. CODE § 62.5-7-5 (2014)) (reconciling two versions of the statute that were inadvertently created during the 2013 legislative session).

77. Pub. L. No. 166-2014, § 9, 2014 Ind. Acts 1967, 1983 (codified at IND. CoDE $§ 6-2.5-2-3$ (2014)).

78. Pub. L. No. 80-2014, $\S 8,2014$ Ind. Acts 945, 957-58 (codified at IND. CoDE $§ 6-2.5-5-$ 49.5 (2014)).

79. Id.

80. Id.

81. See Jegen et al., supra note 61 , at $1180-81$.

82. Pub. L. No. 166-2014, § 10, 2014 Ind. Acts at 1983-84 (amending IND. CoDE $§ 6-2.5-5-$ 46 (2014)). Each year, the public use airport's owner must provide the DOR with a list of retail merchants meeting the first two requirements. Id.

83. Pub. L. No. 87-2014, § 2, 2014 Ind. Acts 992, 992-93 (amending IND. CoDE $§ 6-2.5-5-$ 19.5 (2014)). 
Indiana Code, the exemption for sales of alternative fuel for use in public transportation motor vehicles was revised to exempt "natural gas products" sales instead. ${ }^{84}$

\section{State Income Taxes}

In 2014, the GA reduced the state income tax burden on corporations by installing a tax rate reduction schedule that will gradually lower the tax rate from 2016 through $2021 .^{85}$ Specifically, the income tax rate on corporations will be $6.5 \%$ for taxable years beginning after June 30, 2015 and before July 1, 2016; $6.25 \%$ for taxable years beginning after June 30, 2016 and before July 1, 2017; $6.0 \%$ for taxable years beginning after June 30, 2017 and before July 1, 2018; $5.75 \%$ for taxable years beginning after June 30, 2018 and before July 1, 2019; $5.5 \%$ for taxable years beginning after June 30, 2019 and before July 1, 2020; $5.25 \%$ for taxable years beginning after June 30, 2020 and before July 1, 2021; and finally $4.9 \%$ for taxable years beginning after June $30,2021 .{ }^{86}$

The GA created three new adjusted gross income exemptions. First, Olympic medals, and any accompanying prize money from the United States Olympic Committee, are now exempt from the adjusted gross income tax. ${ }^{87}$ Second, from January 1, 2014 through December 31, 2015, out-of-state entities that contract with an unrelated "qualified third party logistics provider" to obtain "warehousing, management, distribution, transportation, or other services" in connection with legend drugs will not have Indiana-sourced adjusted gross income solely because of the logistics provider's activities within Indiana ${ }^{88}$ Finally, the GA retroactively exempted captive insurers from state income tax starting on January $1,2013 .{ }^{89}$

Beginning on January 1, 2015, Indiana taxpayers may claim an Indiana version of the federal credit for adoption expenses. ${ }^{90}$ The Indiana credit against the tax imposed on adjusted gross income is limited to the lesser of ten percent of the federal credit or $\$ 1000$, subject to the additional limitation that the credit

84. Pub. L. No. 226-2014(ts), § 1, 2014 Ind. Acts 2925, 2925 (amending IND. CoDE § 6-2.55-27 (2014)); see infra notes 131-42 and accompanying text (discussing changes to Indiana's motor fuel excise taxes dealing with alternative fuel and natural gas products).

85. Pub. L. No. 80-2014, § 9, 2014 Ind. Acts at 958-59 (amending IND. CoDE $§ 6-3-2-1$ (2014)).

86. Id.

87. Pub. L. No. 87-2014, § 3, 2014 Ind. Acts 993, 993 (codified at IND. CoDE § 6-3-2-24 (2014)).

88. Pub. L. No. 190-2014, § 13, 2014 Ind. Acts 2402, 2411-12 (codified at IND. CoDE $§ 6-3-$ 2-2.1 (2014)).

89. Pub. L. No. 129-2014, § 1, 2014 Ind. Acts 1481, 1481-82 (amending IND. CoDE § 6-3-22.8 (2014)). Captive insurers were also retroactively exempted from the financial institutions tax and subjected to a new $\$ 2500$ annual tax. See infra notes 127-30 and accompanying text.

90. Pub. L. No. 132-2014, § 1, 2014 Ind. Acts 1530, 1530-31 (codified at IND. CoDE § 6-3-3$13(2014))$. 
cannot exceed the amount that would result in no tax due. ${ }^{91}$ Federal credits that were first allowed for a taxable year beginning after December 1, 2014, and are carried forward into a succeeding taxable year, are included in that carry-forward year when calculating the Indiana credit. ${ }^{92}$

\section{State Tax Liability Credits}

Once again, the GA focused on reducing the number of state tax liability credits. The Prison Investment Credits, the Indiana Riverboat Building Credit, the Voluntary Remediation Credit, the Blended Biodiesel Tax Credits, the Ethanol Production Tax Credit, and the New Employer Tax Credit ended on January 1, 2015. ${ }^{93}$ Another credit, the Energy Savings Tax Credit, ended on July $1,2014 .^{94}$ Because a number of the recently terminated tax credits contained carry forward provisions, the GA created a new transition rule that allows taxpayers to carry forward unused tax credits resulting from a repealed tax credit into taxable years beginning after the tax credit's repeal, subject to the repealed tax credit's limitations on the amount and duration of the carry forwards, which continue to apply as if that tax credit had not been repealed..$^{95}$ Another transition rule, which applies only to the now-repealed Indiana Riverboat Building Credit, grandfathers in taxpayers whose proposed costs to build or refurbish a riverboat were certified as qualified investments before that credit's repeal. ${ }^{96}$ Grandfathered taxpayers may claim the tax credit in the year that the qualified investment is made, provided that the total grandfathered Indiana Riverboat Building Credit cannot exceed one million dollars for each state fiscal year. ${ }^{97}$

The GA expanded two tax credits and made significant modifications to three others. The first expansion involves Neighborhood Assistance Credits, which are now available to taxpayers who contribute to neighborhood organizations that provide "community services, education, or job training services to . . . exoffenders who have completed [their] criminal sentences or are serving a term of probation or parole." 98 The second tax credit expansion only lasts from January

91. Id.

92. Id.

93. Pub. L. No. 190-2014, §§ 16-20, 22, 2014 Ind. Acts 2402, 2413-14 (repealing IND. CODE $\S \S 6-3.1-6,-17,-23,-27,-28,-33(2014))$.

94. Id. $\S 21,2014$ Ind. Acts at 2414 (repealing IND. CODE $§ 6-3.1-31.5$ (2014)).

95. Id. $\S 14,2014$ Ind. Acts at 2412 (codified at IND. CODE $\S 6-3.1-1-4$ (2014)).

96. Id. $\S 15,2014$ Ind. Acts at 2412-13 (codified at IND. CoDE § 6-3.1-1-5 (2014)).

97. Id. If the $\$ 1$ million limit applies for a given fiscal year, the allowed credits are doled out to qualifying taxpayers on first-come, first-served basis (i.e., in chronological order). Id.

98. Pub. L. No. 166-2014, § 12, 2014 Ind. Acts 1967, 1986-87 (amending IND. CoDE $§ 6-3.1-$ 9-2 (2014)). Previously, Neighborhood Assistance Credits were limited to donations supporting (1) certain types of assistance provided to individuals who were not employees of the donor and (2) "community services or crime prevention in an economically disadvantaged area." IND. CODE $\S$ 6-3.1-9-2(a)(1) to -2(a)(2) (2014). 
1, 2015 through December 31, 2018. ${ }^{99}$ During that time period, a taxpayer may receive an Economic Development for a Growing Economy Tax Credit award from the IEDC for fostering the Indiana employment of "students who participate in a course of study that includes a cooperative arrangement between an educational institution and an employer for the training of students in high wage, high demand jobs that require an industry certification." 100 To qualify, the potential employer must "participate[] in at least one (1) cooperative arrangement with an educational institution for the training of students in high wage, high demand jobs that require an industry certification." ${ }^{101}$ The tax credit is only available for employees who participated in a cooperative arrangement between the taxpayer and an educational institution (i.e., a taxpayer does not get credit for employees from another taxpayer's cooperative arrangement). ${ }^{102}$ Furthermore, the taxpayer must enter into a tax credit agreement with the IEDC that (1) contains a detailed description of the taxpayer's cooperative arrangements; (2) requires the taxpayer to report the number of employees who came out of those cooperative arrangements each year, and the income tax revenue withheld by the taxpayer from such employees; (3) states the annual amounts and duration of the tax credits awarded; and (4) requires the taxpayer to maintain its cooperative arrangements for at least two years following the end of the allowed tax credits. ${ }^{103}$ A taxpayer's failure to maintain the required cooperative arrangements will subject the disqualified tax credit to recapture by the DOR. ${ }^{104}$

The first significant modification is to the Income Tax Credit for Property Taxes Paid on Homesteads. ${ }^{105}$ Effective for taxable years beginning after December 31,2014, the modified credit includes unearned income in the test to determine whether a taxpayer qualifies for the credit and in the calculation of the credit amount. ${ }^{106}$ That change is accomplished by requiring the taxpayer to use "Indiana income" (i.e., "adjusted gross income of an individual taxpayer, and the individual's spouse, if the individual filed a joint adjusted gross income tax return") in place of "earned income." 107 Also, the GA limited the Tax Credit for Natural Gas Powered Vehicles to natural gas powered vehicles that are "purchased or leased from a dealer located in Indiana," 108 and modified the calculation of the total tax credit allowed to all persons for a particular year to tie

99. Pub. L. No. 167-2014, § 5, 2014 Ind. Acts 2013, 2015 (amending IND. CoDE § 6-3.1-1313 (2014)).

100. Id.

101. Id. $\S 7,2014$ Ind. Acts at 2016-17 (codified at IND. CODE $§ 6-3.1-13-15.7$ (2014)).

102. Id. $\S 8,2014$ Ind. Acts at 2017-18 (codified at IND. CODE $§ 6-3.1-13-19.7$ (2014)).

103. $I d$.

104. Id. $\S 8,2014$ Ind. Acts at 2017 (codified at IND. CODE § 6-3.1-13-19.7(a)(4) (2014)).

105. Pub. L. No. 166-2014, $\S \S 22-24,2014$ Ind. Acts 1967, 1990-92 (amending IND. CodE $\S \S 6-3.1-20-1,-4,-5(2014))$.

106. Id. $\S \S 23-24,2014$ Ind. Acts at 1990-92 (amending IND. CODE $\S \S 6-3.1-20-4,-5$ (2014)).

107. Id. § 22, 2014 Ind. Acts at 1990-92 (amending IND. CODE § 6-3.1-20-1 (2014)).

108. Pub. L. No. 212-2014, § 1, 2014 Ind. Acts 2544, 2544 (amending IND. CODE $\S 6-3.1-$ 34.6-6 (2014)). 
it to the state gross retail and use tax revenue from the purchase of natural gas products to fuel motor vehicles. ${ }^{109}$ Prior to those changes, the tax credit did not depend on the transferor's location and the maximum credit was tied to tax revenue from the sale of "alternative fuels" used in providing public transportation. ${ }^{110}$ In addition, the GA modified the Industrial Recovery Tax Credit to permit a pass-through entity's owners to claim its tax credit in proportion to their share of the entity's distributive income (in addition to any Industrial Recovery Tax Credit that the owners may be entitled to on their own). ${ }^{11}$

More modest changes were made to a number of other tax credits. First, responsibility for administering portions of the Historic Rehabilitation Credit and the Residential Historic Rehabilitation Credit was transferred from the Division of Historic Preservation and Archeology to the Office of Community and Rural Affairs, and the Tax Court is now empowered to hear taxpayer appeals from that Office. ${ }^{112}$ Second, the GA prohibited the use of a Venture Capital Investment Credit certificate or tax credit as a security for purposes of Title 23 of the Indiana Code (Business and Other Associations). ${ }^{113}$ Finally, a taxpayer may not claim a School Scholarship Tax Credit for making a contribution that is used to provide a scholarship to a participant in the state's early education grant pilot program. ${ }^{114}$

\section{E. Local Taxes}

Two significant changes in local taxation occurred in $2014 .{ }^{115}$ First, the GA created a credit for income taxes paid to a "county, city, town, or other local government entity located outside Indiana" that may be taken against the taxpayer's CEDIT liability. ${ }^{116}$ The new tax credit may not reduce the taxpayer's CEDIT liability below the amount of CEDIT that would have been due if the income in question were simply excluded from the taxpayer's CEDIT liability

109. Id. § 2, 2014 Ind. Acts at 2544 (amending IND. CODE § 6-3.1-34.6-10 (2014)).

110. Id.

111. Pub. L. No. 166-2014, § 13, 2014 Ind. Acts 1987, 1987 (codified at IND. CoDE $§ 6-3.1-$ 11-24 (2014)).

112. Id. $\S \S 15,18,27,30,2014$ Ind. Acts at 1988-89, 1993-94 (amending IND. CoDE $\S \S 6-3.1-$ 16-2, -16-9, -22-2, -22-10 (2015)).

113. Pub. L. No. 106-2014, § 1, 2014 Ind. Acts 1182, 1182 (codified at IND. CoDE $§ 6-3.1-24-$ 14 (2014)).

114. Pub. L. No. 202-2014, § 1, 2014 Ind. Acts 2507, 2507 (amending IND. CoDE $§ 6-3.1-$ 30.5-7 (2014)). The GA created the early education grant pilot program in 2014 to promote the provision of educational services to four-year-old children from lower-income families in Indiana. Id. $\S 2,2014$ Ind. Acts at 2507-11 (codified at IND. CODE $\S 12-17.2-7.2$ (2014)).

115. The GA also made a few minor procedural changes and added "motor driven cycles" to the list of vehicles that may be subjected to a county's license excise surtax. Pub. L. No. 221-2014, $\S 4,2014$ Ind. Acts 2862, 2863 (amending IND. CoDE § 6-3.5-4-2 (2014)).

116. Pub. L. No. 190-2014, $§ 23,2014$ Ind. Acts 2402, 2414 (codified at IND. CODE $§ 6-3.5-7-$ $8.1(2014))$. 
determination. ${ }^{117}$ Furthermore, no credit is available if the other governmental entity provides a credit for the taxpayer's CEDIT liability. ${ }^{118}$

Second, the GA expanded the CAGIT, COIT, and CEDIT for counties in central Indiana to permit those counties to use their local taxes for the development of new public transportation projects. ${ }^{119}$ The county fiscal bodies of Hamilton County and Marion County are now authorized to pay for public transportation projects that are approved by the voters of those counties by imposing an additional CEDIT tax rate ranging from $0.1 \%$ to $0.25 \% .{ }^{120}$ If the new public transportation project is only approved by the voters of a township within the county, then the relevant county fiscal body is authorized to impose a similar CEDIT tax rate increase for that township. ${ }^{121}$ Appropriately, that township-specific CEDIT tax rate increase is limited to the taxpayers residing in the township that approved the project. ${ }^{122}$ The GA installed similar public transportation project financing systems for Hancock County and Johnson County, using the CAGIT, ${ }^{123}$ and for Delaware County and Madison County, using the COIT. ${ }^{124}$

\section{F. Taxation of Financial Institutions}

In 2014, the GA continued reducing the franchise tax burden on corporations doing business as a financial institution in Indiana. Last year, the GA installed a tax rate schedule that gradually reduced the tax rate from $8.5 \%$ in 2013 to $6.5 \%$ starting in $2017 .{ }^{125}$ This year, the GA extended that reduction schedule through 2023. Specifically, the franchise tax rate will be $6.5 \%$ for taxable years beginning after December 31, 2016 and before January 1, 2019; 6.25\% for taxable years beginning after December 31, 2018 and before January 1, 2020; $6.0 \%$ for taxable years beginning after December 31, 2019 and before January 1,$2021 ; 5.5 \%$ for taxable years beginning after December 31, 2020 and before January 1, 2022; 5.0\% for taxable years beginning after December 31, 2021 and before January 1,2023 ; and finally $4.9 \%$ for taxable years beginning after December 31, 2022. ${ }^{126}$

117. Id.

118. Id.

119. See Pub. L. No. 153-2014, § 8, 2014 Ind. Acts 1799, 1815-18 (amending IND. CoDE § 6-3.5-6-18 (2014)) (adding voter-approved public transportation projects to the list of things that may be paid for with COIT revenue).

120. Id. $\S 14,2014$ Ind. Acts at 1830-35 (amending IND. CODE $\S 6-3.5-7-26$ (2014)).

121. Id.

122. Id. $\S 15,2014$ Ind. Acts at 1835-36 (codified at IND. CODE $§ 6-3.5-7-29$ (2014)).

123. Id. $\S \S 4-5,2014$ Ind. Acts at 1804-10 (amending IND. CODE $\S 6-3.5-1.1-24$ (2014) and adding IND. CODE $§ 6-3.5-1.1-29$ (2014)).

124. Id. $\S \S 10-11,2014$ Ind. Acts at 1818-24 (amending IND. CODE § 6-3.5-6-30 (2014) and adding IND. CODE $\S 6-3.5-6-34$ (2014)).

125. Jegen et al., supra note 61 , at 1186 .

126. Pub. L. No. 80-2014, $\S 10,2014$ Ind. Acts 945, 959-61 (amending IND. CoDE $§ 6-5.5-2-1$ 
In addition, the GA addressed the taxation of captive insurers by retroactively excluding them from the financial institutions tax starting on January 1, 2013, ${ }^{127}$ and by subjecting them to an annual $\$ 2500$ tax for the privilege of doing business in Indiana. ${ }^{128}$ For this purpose, a "captive insurer" is a foreign-controlled foreign company "whose exclusive purpose is to insure property and casualty risks" of related business entities and who is owned by a person conducting business in Indiana. ${ }^{129}$ In addition, the captive insurer's annual direct written premiums cannot exceed two million dollars. ${ }^{130}$

\section{G. Excise Taxes and Other Miscellaneous Taxes}

As was the case last year, much of the GA's work on excise taxes during 2014 dealt with motor vehicles and fuel. A number of those changes involved natural gas products and alternative fuels. The GA modified the definition of "special fuel," for purposes of the Special Fuel Tax in Chapter 2.5 of Indiana Code section 6-6, to include natural gas products but not alternative fuels. ${ }^{131} \mathrm{In}$ conjunction with that change, the GA defined "natural gas product" as "(1) a liquid or compressed natural gas product; or (2) a combination of liquefied petroleum gas and a compressed natural gas product; used in an internal combustion engine or motor to propel any form of vehicle, machine, or mechanical contrivance"132 and removed natural gas products from the "alternative fuel" definition. ${ }^{133}$

Also in the area of alternative fuels, the GA created a new regulatory and fee system that took effect on January 1, 2014. ${ }^{134}$ The new rules apply to the sale of "alternative fuel," which is defined as "liquefied petroleum gas used in an internal combustion engine ... to propel any form of vehicle" (including butane and propane). ${ }^{135}$ Only a person with a propane dealer license obtained from the DOR may sell alternative fuel in Indiana. ${ }^{136}$ The license costs fifty dollars. ${ }^{137}$ Licensed dealers may only dispense alternative fuel to a motor vehicle bearing an "alternative fuel decal," "138 which must be displayed on the vehicle's front

(2014)).

127. Pub. L. No. 129-2014, $\S 2,2014$ Ind. Acts 1481, 1482 (amending IND. CODE $§ 6-5.5-2-7$ (2014)).

128. Id. $\S 2,2014$ Ind. Acts at 1482-83 (codified at IND. CODE $\S 27-2-2-2.3$ (2014)).

129. $I d$.

130. Id.

131. Pub. L. No. 212-2014, § 6, 2014 Ind. Acts 2544, 2546 (amending IND. CODE $§ 6-6-2.5-22$ (2014)).

132. Id. $\S 5,2014$ Ind. Acts at 2545-46 (amending IND. CODE $\S 6-6-2.5-16.5$ (2014)).

133. Id. $\S 4,2014$ Ind. Acts at 2545 (amending IND. CODE $\S 6-6-2.5-1$ (2014)).

134. Id. § 9, 2014 Ind. Acts at 2547-50 (codified at IND. CODE § 6-6-14 (2014)).

135. Id. $\S 9,2014$ Ind. Acts at 2547 (codified at IND. CODE $\S 6-6-14-1$ (2014)).

136. Id. $\S 9,2014$ Ind. Acts at 2548 (codified at IND. CODE § 6-6-14-6(a) (2014)).

137. $I d$.

138. Id. $\S 9,2014$ Ind. Acts at 2550 (codified at IND. CODE $\S 6-6-14-9$ (2014)). 
windshield. ${ }^{139}$ The owner of any registered motor vehicle using an alternative fuel in Indiana must obtain the required decal by paying an annual fee (e.g., $\$ 100$ for most passenger motor vehicles) to the DOR. ${ }^{140}$ Upon entering Indiana, an alternative fuel motor vehicle that is registered in another state must obtain a temporary trip permit that costs $\$ 5.50$ and lasts for seventy-two hours. ${ }^{141} \mathrm{~A}$ temporary trip permit may be obtained from a licensed propane dealer, who must remit the resulting fees to the DOR on a monthly basis. ${ }^{142}$

In other parts of the motor vehicle and fuel area, the GA made minor modifications to several existing taxes. First, it moved the recently created Road Tax Credit from an annual basis to a calendar quarter basis effective on July 1, 2014. ${ }^{143}$ Second, the GA exempted motor driven cycles from the regular motor vehicle excise tax levied under Indiana Code section 6-6-5-5 and imposed an annual ten dollar excise tax in its place. ${ }^{144}$ Third, the GA extended the boat excise tax to motorboats that are registered outside of Indiana, but are docked on the Indiana part of Lake Michigan for more than 180 consecutive days. ${ }^{145}$ The boat excise tax is due on the following day (i.e., on the day after the 180th consecutive day that the motorboat is docked on the Indiana part of Lake Michigan). ${ }^{146}$

In other areas, the GA repealed the Hazardous Waste Disposal Tax, effective July $1,2014 .{ }^{147}$ In addition, all cigarette tax reporting and payments must be submitted electronically. ${ }^{148}$ The same is true for the tobacco products tax. ${ }^{149}$

\section{H. Tax Administration Matters}

Finally, the GA made several adjustments to the statutes governing the DOR's administration of Indiana's tax system. Taxpayers no longer need to include payment of their expected taxes with their filing extension requests; however, those taxes are still due by the original return due date and a failure to

139. Id. $\S 9,2014$ Ind. Acts at 2549 (codified at IND. CODE § 6-6-14-8(a) (2014)).

140. Id. $\S 9,2014$ Ind. Acts at 2545-49 (codified at IND. CODE § 6-6-14-4(a) (2014)).

141. Id. $\S 9,2014$ Ind. Acts at 2548 (codified at IND. CODE $\S 6-6-14-5$ (2014)).

142. Id. $\S 9,2014$ Ind. Acts at 2548 (codified at IND. CODE $\S 6-6-14-5(\mathrm{~b})$ (2014)).

143. Id. $\S \S 7-8,2014$ Ind. Acts at 2546-47 (amending IND. CODE §§ 6-6-12-5, -6 (2014)); see also Jegen et al., supra note 61, at 1189 (discussing the Road Tax Credit's creation in 2013).

144. Pub. L. No. 221-2014, § 5, 2014 Ind. Acts 2862, 2863-64 (codified at IND. CoDE § 6-6-5$5.6(2014))$. In addition, counties may still impose a license excise surtax on motor driven cycles. See supra note 115.

145. Pub. L. No. 219-2014, § 3, 2014 Ind. Acts 2817, 2818 (amending IND. CoDE § 6-6-11-9 (2014)).

146. Id. $\S 4,2014$ Ind. Acts at 2818-19 (amending IND. CODE § 6-6-11-14 (2014)).

147. Pub. L. No. 220-2014, § 1, 2014 Ind. Acts 2841, 2841 (repealing IND. CoDE $§ 6-6-6.6$ (2014)).

148. Pub. L. No. 166-2014, §33, 2014 Ind. Acts 1967, 1995 (codified at IND. CoDE $§ 6-7-1-$ 37 (2014)).

149. Id. $\S 34,2014$ Ind. Acts at 1995-96 (amending IND. CoDE $\S 6-7-2-12$ (2014)). 
pay penalty still applies if at least ninety percent of those taxes are not paid on time. ${ }^{150}$ Furthermore, a taxpayer can now receive an extension to file an adjusted gross income tax return, or financial institution tax return, even though that taxpayer has not requested the comparable federal filing extension from the Internal Revenue Service. ${ }^{151}$ Regardless of whether a federal extension was granted, the Indiana filing extension continues for thirty days beyond the end of the potentially applicable federal extension. ${ }^{152}$

In other administrative matters, the GA (1) clarified that the interest rate applied to taxpayer underpayments and deficiencies is pegged to the average investment yield on state general fund money for the state's previous fiscal year; ${ }^{153}$ (2) relieved the DOR of its obligation to include a voter registration form in each state adjusted gross income tax booklet that it mails to a taxpayer with an Indiana address, ${ }^{154}$ (3) required the DOR, the Indiana Secretary of State, and the Indiana Department of Workforce Development to create an Internet web site that provides a single point of contact for a person wanting to satisfy the requirements for transacting business in the state and that shares information among those three agencies; ${ }^{155}$ and (4) permitted the DOR to deny or suspend oversize or overweight vehicle permits when the applicant or holder "is delinquent in paying escort fees to the state police department."

\section{INDIANA TAX COURT DECISIONS}

The Indiana Tax Court issued a variety of opinions and decisions from January 23, 2014 to December 31, 2014. Specifically, the Indiana Tax Court issued twenty-eight published opinions and decisions: twelve of which concern the Indiana real property tax, six of which concern the Indiana local tax, five of which concern the Indiana sales and use tax, one of which concerns the Indiana corporate income tax and four of which concern Indiana tax procedure. Summaries of each of these opinions and decisions are stated below.

\section{A. Real Property Tax}

1. Thorsness, v. Porter County Assessor. ${ }^{157}$-William W. Thorsness

150. Pub. L. No. 190-2014, § 26, 2014 Ind. Acts 2402, 2417-19 (amending IND. CoDE § 6-8.16-1 (2014)).

151. Id.

152. Id.

153. Pub. L. No. 113-2014, § 13, 2014 Ind. Acts 1299, 1306-07 (amending IND. CODE § 6-8.110-1 (2014)).

154. Pub. L. No. 64-2014, § 73, 2014 Ind. Acts 668, 727 (repealing IND. CoDE $§ 6-8.1-3-19$ (2014)).

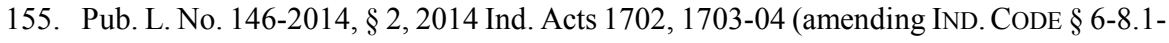
3-23 (2014)).

156. Pub. L. No. 190-2014, $\S 25,2014$ Ind. Acts at 2416-17 (amending IND. CODE $§ 6-8.1-4-4$ (2014)).

157. 3 N.E.3d 49 (Ind. Tax Ct. 2014). 
purchased real property on January 31,2007 for $\$ 1,650,000 .{ }^{158}$ With respect to the March 1, 2007, assessment date, the Assessor assessed the property at $\$ 1,647,800 .{ }^{159}$ Thorsness subsequently appealed the assessment to the PTABOA, and when the PTABOA denied Thorsness' appeal, Thorsness filed an appeal with the IBTR. ${ }^{160}$

At the IBTR hearing, Thorsness argued that the assessment failed to comport with the uniform and equal mandate of Indiana's constitution, because Thorsness' property was assessed at $99.9 \%$ of its sales price, when six other residential properties were assessed on average, at only $79.5 \%{ }^{161}$ To support his position, Thorsness presented a one-page spreadsheet ${ }^{162}$ that listed: the addresses of the six other properties in Dune Acres; the dates in 2005 and 2006 in which each of the six properties were sold and their reported sales prices; the properties' 2006 and 2007 assessed values; and, the ratio of each property's sales price to its assessed value. ${ }^{163}$ Based on the above evidence, Thorsness requested the IBTR to reduce the assessment so that he could be treated as were his neighbors. ${ }^{164}$ On December 29, 2010, the IBTR issued a final determination affirming the Assessor's assessment, because the evidence was not considered to be probative in demonstrating that the property was inequitably assessed. ${ }^{165}$ Thus, Thorsness appealed to the Indiana Tax Court. ${ }^{166}$

On appeal, Thorsness presented two issues. ${ }^{167}$ First, Thorsness claimed that the IBTR erred in determining that he, and not the Assessor, bore the burden of proof at the administrative hearing, and second, Thorsness claimed that the IBTR erred in determining that Thorsness' evidence was not probative in demonstrating that the Assessor's assessment lacked uniformity. ${ }^{168}$

However, the Indiana Tax Court held that in a real property assessment case, the taxpayer, and not the Assessor, bore the burden of proof at the administrative hearing before the IBTR, because the burden-shifting rule, which is contained in former Ind. Code section 6-1.1-15-1(p), did not apply to the evaluation required by the taxpayer's uniformity and equality claim. ${ }^{169}$ And second, through Indiana Constitution article X, section 1(a) and because the taxpayer's study ratio was not probative in demonstrating that the Assessor's assessment lacked uniformity, because the IBTR had properly determined such evidence was not probative in demonstrating that the taxpayer's property was assessed and taxed at a level

158. Id. at 50 .

159. Id.

160. Id.

161. Id.

162. Id.

163. Id.

164. Id.

165. Id.

166. Id.

167. Id. at 52 .

168. Id.

169. Id. at 53-54. 
which exceeded a common level within the township. ${ }^{170}$

As such, the issue of burden-shifting through Ind. Code section 6-1.1-15-1(p) was seen as being clear and unambiguous because the assessment needs to be increased by more than five percent for the Assessor to have the burden of proof. ${ }^{171}$ In Indiana, a property's assessment is the value placed on the property that reflects its market value-in-use. ${ }^{172}$

However, Thorsness did not claim the market in use issue. ${ }^{173}$ In other words, Thorsness wanted his otherwise correct property assessment to be reduced by $20.5 \%$ so that the assessment of his property was on par with the assessment to market value ratios of other persons' properties. ${ }^{174}$ However, the Indiana Tax Court determined that Ind. Code section 6-1.1-15-1(p) does not apply to the relational evaluation required by a uniformity and equality claim that seeks an equalization adjustment. ${ }^{175}$ Consequently, the Indiana Tax Court did not reverse the IBTR's final determination on that basis. ${ }^{176}$ Next, the Indiana Tax Court determined that the evidence was relevant, but the IBTR did not err in determining that the evidence "was not probative in demonstrating that Thorness's property was assessed and taxed at a level that exceeded the common level within Westchester Township overall."177 Accordingly, the Indiana Tax Court did not conclude the IBTR erred on this basis. ${ }^{178}$ Therefore, the Indiana Tax Court upheld the Assessor's assessment. ${ }^{179}$

2. Fraternal Order of Eagles \#3988, Inc. v. Morgan County Property Tax Assessment Board of Appeals. ${ }^{180}$ _During the 2006 tax year, the Fraternal Order of Eagles \#3988 ("Eagles") owned a 10,500 square foot lodge situated on 2.23 acres of land. ${ }^{181}$ Eagles used the property to raise funds for charitable organizations, to collect donations for families in need, and to host private events for the members. ${ }^{182}$ In addition, Eagles occasionally allowed other charitable organizations to use the property for no charge. ${ }^{183}$

On May 15, 2006, Eagles filed an application for a property tax exemption with the PTABOA requesting either: a fraternal beneficiary association exemption; or, a charitable purposes exemption for the 2006 tax year with respect

170. Id.

171. Id. at 52 .

172. "Market value-in-use" is another way of saying market value. Id. at 53-54.

173. Id.

174. Id.

175. Id.

176. $I d$.

177. Id. at 54 .

178. Id.

179. Id.

180. 5 N.E.3d 1195 (Ind. Tax Ct. 2014).

181. Id. at 1198 .

182. Id.

183. Id. 
to its real and personal property. ${ }^{184}$ However, the PTABOA denied Eagles' application in its entirety, and therefore, Eagles appealed the assessment to the IBTR. $^{185}$ On August 23, 2011, the IBTR held a hearing during at which the Eagles presented, among other things, its charitable donation records for 2003 through 2006, which provided Eagles' monthly profit/loss statements for 2005, ${ }^{186}$ several affidavits, and a Usage Study ${ }^{187}$ in order to demonstrate that Eagles used its property for fraternal and charitable purposes. ${ }^{188}$ However, on December 9, 2011, the IBTR issued a final determination, holding that Eagles was not entitled to either the fraternal beneficiary association exemption or to the charitable purposes exemption. ${ }^{189}$

On appeal to the Indiana Tax Court, Eagles contended that the IBTR's final determination must be reversed for the following two reasons: (1) that the IBTR's determination failed to establish a prima facie case to which Eagles was entitled through Ind. Code section 6-1.1-10-23; and (2) that the IBTR's determination failed to establish a prima facie case, to which Eagles was entitled through Ind. Code section 6-1.1-10-16 and that such failure is also contrary to law. ${ }^{190}$

Further, while on appeal, Eagles claimed the IBTR's determination is contrary to law because it conflicts with the common law definition of "fraternal beneficiary association" as provided by in a 1944 Attorney General Opinion. ${ }^{191}$ However, because a final determination of the IBTR is contrary to law if it violates any statute, constitutional provision, legal principle, or rule of substantive or procedural law, and because opinions of the Attorney General have no precedential value, Eagles did not show that the IBTR's final determination was contrary to law. ${ }^{192}$

Further, because Eagles was required to present probative evidence demonstrating that Eagles satisfied the statutory definition of a "fraternal beneficiary association" as set forth in Ind. Code section 27-11-1-1, but Eagles did not do so, the Indiana Tax Court determined no basis for reversing the

184. $I d$.

185. Id.

186. The affiants provided sworn testimony that Eagles' members used the property $100 \%$ of the time and that charitable organizations used the property at no charge. Id. at 1198 n.3.

187. The Usage Study indicated that the Eagles' lodge was comprised of a social room, entertainment room, lodge room, pool/dart room, kitchen, offices, storage areas, restrooms, and corridors. Id. at $1198 \mathrm{n}$.4. It also identified the events that took place in these rooms (including the times) between March 2005 and February 2006. Id. For example, the Usage Study provided that Eagles' members used the entertainment room for karaoke and the social room for meetings, bingo, and dances on certain days at certain times. $I d$.

188. Id. at 1198 .

189. Id.

190. See generally id.

191. Id. at 1199-1202.

192. Id. 
IBTR's findings. ${ }^{193}$ Also, Eagles failed to show how its evidence satisfied each element of the definition of a "fraternal beneficiary association" as defined through Ind. Code section 27-11-1-1. ${ }^{194}$ Moreover, Eagles' recognition as an IRC section 501(c)(8) fraternal beneficiary society, order, or association for federal income tax purposes does not, by itself, establish that Eagles met all the definitional requirements contained in Ind. Code section 27-11-1-1. ${ }^{195}$

Next, the charitable purposes exemption, set forth in Ind. Code section 6-1.1$10-16$, provides that all or part of a building is exempt from property taxation if it is owned, occupied, and used by a person for charitable purposes. ${ }^{196}$ This exemption generally extends to land on which an exempt building is situated and the personal property that is contained within. ${ }^{197}$ Accordingly, a taxpayer seeking a charitable purpose exemption through Ind. Code section 6-1.1-10-16(a) must demonstrate that such taxpayer owns, occupies, and either exclusively or predominately uses its property for charitable purposes. ${ }^{198}$

A review of Eagles' presentation indicates that Eagles used the property for a variety of social and recreational purposes (e.g., gambling, drinking, dancing, karaoke, pool and/or dart tournaments, and general relaxation) and for charitable purposes. ${ }^{199}$ In this case, the evidence displayed that Eagles used the property for a variety of both social and recreational purposes but Eagles did not provide the IBTR with a comparison of the relative amounts of time that the lodge was used for exempt purposes and for non-exempt purposes. ${ }^{200}$ Thus, Eagles' failure to provide this comparison was fatal to the claim for either a full or a partial exemption. ${ }^{201}$ Consequently, Eagles failed to show that the activities claimed were exclusively or predominately used for charitable purposes. ${ }^{202}$

3. Jones v. Jefferson County Assessor. ${ }^{203}$ - On July 17, 2013, the IBTR issued a final determination regarding the Joneses' residential real property assessment for the 2008 and 2009 tax years. ${ }^{204}$ Subsequently, the Joneses initiated an original tax appeal in the Indiana Tax Court challenge to that final determination. ${ }^{205}$ The Assessor's attorney entered an appearance and filed an answer on October 2, 2013. ${ }^{206}$ Thereafter, the Indiana Tax Court scheduled a

193. Id.

194. Id.

195. Id.

196. Id at 1201-02.

197. Id.

198. Id.

199. Id.

200. $I d$.

201. Id.

202. $I d$.

203. 6 N.E.3d 1048 (Ind. Tax Ct. 2014).

204. Id.

205. Id.

206. Id. 
conference. ${ }^{207}$ The next day, the Joneses moved for a default judgment on the basis that the Assessor failed to file an answer within thirty days of the filing of the Joneses' complaint. ${ }^{208}$

The Assessor filed a response opposing the motion on October 29, 2013. ${ }^{209}$ In an order dated November 20, 2013, the Indiana Tax Court denied the Joneses' motion for default judgment, explaining that because the Assessor filed an answer before the Joneses filed their motion, the fact that the answer was late was of no consequence. ${ }^{210}$ In denying the motion, the Indiana Tax Court also explained that while procedural rules are extremely important, they are merely a means for achieving orderly and speedy justice. ${ }^{211}$ Indeed, the Indiana Tax Court's "function is to serve the truth and to decide legal issues, not clear the dockets by utilization of unnecessarily narrow technical interpretations of the procedural rules." 212 In denying the motion, the Indiana Tax Court also explained its long-standing policy that cases should be decided on the merits. ${ }^{213}$ Consequently, given the particular facts of the case, the Indiana Tax Court determined that the failure did not warrant a dismissal. ${ }^{214}$

The Joneses timely filed their initial brief and the Assessor filed a motion to dismiss the case, as well as a brief. ${ }^{215}$ However, the Assessor's brief did not address the merits of the case but instead provided a legal argument to support the motion to dismiss; specifically, that the Joneses had failed to timely file a request for the IBTR to prepare a certified copy of its administrative record as the Joneses were required to do through Indiana Tax Court Rule 3. ${ }^{216}$

An original tax appeal from a final determination of the IBTR is commenced by filing a petition in the Indiana Tax Court and filing a written notice of appeal with the IBTR. ${ }^{217}$ If the petitioner does not include in the petition a request that the IBTR prepare a certified copy of the agency record, then the petitioner is required to file a separate request for such record through Indiana Tax Court Rule 3, section (e). ${ }^{218}$ In Indiana Tax Court Rule 3, section (b), the petitioner is required to request the IBTR to prepare a certified copy of the agency record within thirty days after filing the petition. ${ }^{219}$ Further, the petitioner is required to transmit a certified copy of the record to the Indiana Tax Court within thirty days after having received notification from the IBTR that the record has been

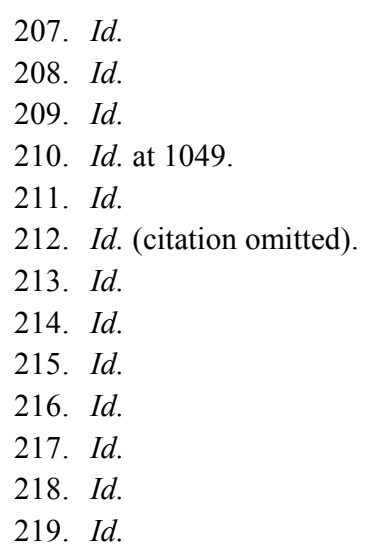


prepared. $^{220}$

When the Joneses filed their complaint with the Indiana Tax Court on August 28,2013 , they did not include a request that the IBTR prepare a certified copy of the administrative record. ${ }^{221}$ Consequently, through Indiana Tax Court Rule 3, they had until September 27, 2013, to file a separate request for the administrative record to be prepared. ${ }^{222}$ Because the Joneses failed to meet that September deadline, the Assessor argued that the Joneses "have not properly initiated their action before the Indiana Tax Court," and therefore, the complaint should be dismissed. ${ }^{223}$

However, through a series of cases, the Indiana Supreme Court has held that a failure to timely file the administrative record pursuant to Indiana Tax Court Rule 3 is the type of legal error or procedural defect which, if not objected to at the appropriate time, is waived. ${ }^{224}$ Further, if a petitioner fails to timely request that a certified copy of the IBTR's administrative record be prepared through Indiana Tax Court Rule 3, then such objection is waived. ${ }^{225}$

Thus, the taxpayers' failure to timely request and file the IBTR's administrative record did not warrant a dismissal of the taxpayers' original tax appeal because the Assessor had waived the Assessor's objection to timeliness, given that the Assessor did not object to the taxpayers' failure at the appropriate time. ${ }^{226}$ Given the particular facts here, the Indiana Tax Court determined that the Assessor had waived the objection to the timeliness of the taxpayers' request, given that the Assessor did not object to the taxpayers' failure at the appropriate time. ${ }^{227}$

4. Washington Park Cemetery Ass'n v. Marion County Assessor. ${ }^{228}$ Washington Park is a non-profit cemetery association that owns a cemetery, mausoleum, and crematory complex in Indiana, along a Community Life Center. $^{229}$ For many years, Washington Park's entire complex received an exemption from property taxation pursuant to Ind. Code section 6-1.1-10-27. ${ }^{230}$ However, in 2013, Washington Park received notice that the exemption previously applied to the Community Life Center had been removed. ${ }^{231}$ Thus, Washington Park filed with the IBTR both a petition to the IBTR and a petition with the PTABOA for reinstating the exemption. ${ }^{232}$ The PTABOA denied the

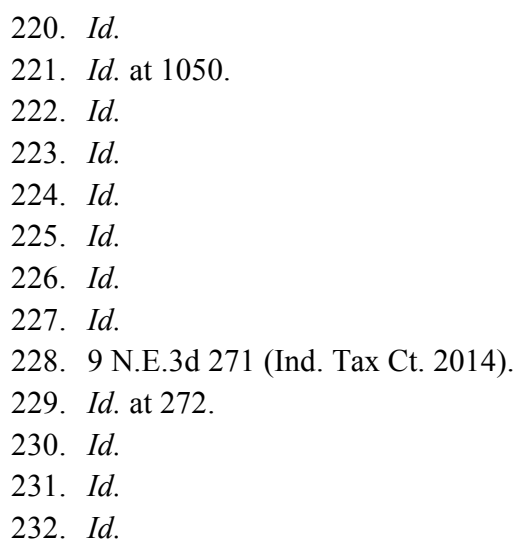


requests, and Washington Park appealed that denial to the IBTR on December $13,2013 .{ }^{233}$

As of April 14, 2014, the IBTR had not scheduled a hearing with respect to this matter. ${ }^{234}$ Therefore, Washington Park filed its petition to the Indiana Tax Court to enjoin the collection of property taxes resulting from the exemption's removal. ${ }^{235}$ Subsequently, Marion County filed its motion, averring that the Indiana Tax Court lacked subject matter jurisdiction with respect to this matter and the Indiana Tax Court conducted a hearing on May 8, 2014. ${ }^{236}$ The stated reason for the exemption's removal was that special events, such as weddings, sometimes were held there and there were no burials at that location. ${ }^{237}$ In its petition, Washington Park acknowledged it had not received a final determination from the IBTR. ${ }^{238}$ Accordingly, Washington Park admitted that its case was not yet ripe to file a petition for an original tax appeal ${ }^{239}$ with the Indiana Tax Court. Nonetheless, Washington Park maintained that the Indiana Tax Court had subject matter jurisdiction to rule on its petition. ${ }^{240}$

Washington Park first argued that requiring a summary of the issues that petitioner "will raise" 241 in the original tax appeal, contemplates the filing of an injunction request prior to the filing of an original tax appeal because if an original tax appeal had been filed, that filing would suffice to have "raised" the issues. ${ }^{242}$ However, the Indiana Tax Court determined that Washington Park had read the Indiana Code in a vacuum. ${ }^{243}$ Ind. Code section 33-26-6-2(a) states that a taxpayer who wishes to initiate an original tax appeal must file a petition in the Indiana Tax Court in order to set aside the final determination of the Indiana Department of State Revenue or of the IBTR. ${ }^{244}$ And, if a taxpayer fails to comply with any such statutory requirement, then the Indiana Tax Court does not have jurisdiction. ${ }^{245}$ Thus, when section (b) indicates that a taxpayer may file an injunction petition, it is assumed that an original tax appeal has been initiated under section (a). ${ }^{246}$ For these reasons, the Indiana Tax Court determined that the language "will raise" in Ind. Code section 33-26-6-2(b)(1) did not mean injunctive relief could be granted before an original tax appeal has been initiated

\footnotetext{
233. $I d$.

234. Id.

235. Id.

236. $I d$.

237. Id.

238. $I d$.

239. Id. at 273 .

240. Id.

241. Id. at 272 .

242. Id. at 273.

243. Id.

244. Id.

245. Id.

246. Id.
} 
Park's Petition. ${ }^{247}$

Next, Washington Park asserted that the nature of a preliminary injunction typically seeks an order from the Indiana Tax Court before the full presentation of evidence on the merits, not after. ${ }^{248}$ Further, by authorizing the Indiana Tax Court to grant injunctive relief and by authorizing the Indiana Tax Court to hold an evidentiary hearing, the GA had authorized the Indiana Tax Court to hear evidence before a dispute has been fully litigated. ${ }^{249}$ But this asks the Indiana Tax Court to exert power where it has none. ${ }^{250}$ To repeat, the Indiana Tax Court may grant injunctive relief only if an original tax appeal is pending.

Finally, Washington Park argued that the principle of stare decisis would require the Indiana Tax Court to follow the rationale and holding in American Trucking Associations, Inc. v. Indiana. ${ }^{251}$ But, while the rationale and holding in American Trucking does indeed support Washington Park's position, in this case the Indiana Tax Court determined that position to be unpersuasive. ${ }^{252}$

Given the weight of issues, the taxpayer's petition to enjoin collection was dismissed by the Indiana Tax Court for lack of subject matter jurisdiction because the taxpayer had not yet received a final determination from the IBTR. ${ }^{253}$

5. West Ohio II, LLC v. Marion County Assessor. ${ }^{254}$-West Ohio owned a multi-tenant office building and parking garage in Indiana. ${ }^{255}$ As of a March 2013 assessment, West Ohio's property was valued at $\$ 39,314,000 .{ }^{256}$ Believing that the property was overvalued, West Ohio appealed the assessment with the Marion County Assessor. ${ }^{257}$ West Ohio provided the Assessor with a market value-in-use appraisal of its property to support its position. ${ }^{258}$

As of April 2014, the PTABOA had yet to schedule a hearing on West Ohio's appeal. ${ }^{259}$ Therefore, West Ohio filed its petition with the Indiana Tax Court, asking the Court to enjoin the collection of property taxes related to the disputed portion of its $\$ 39,314,000$ assessment. ${ }^{260}$ Marion County subsequently filed its motion, asserting that the Indiana Tax Court lacked subject matter jurisdiction with respect to this matter. ${ }^{261}$

Thereafter, the Indiana Tax Court held that it did not have subject matter

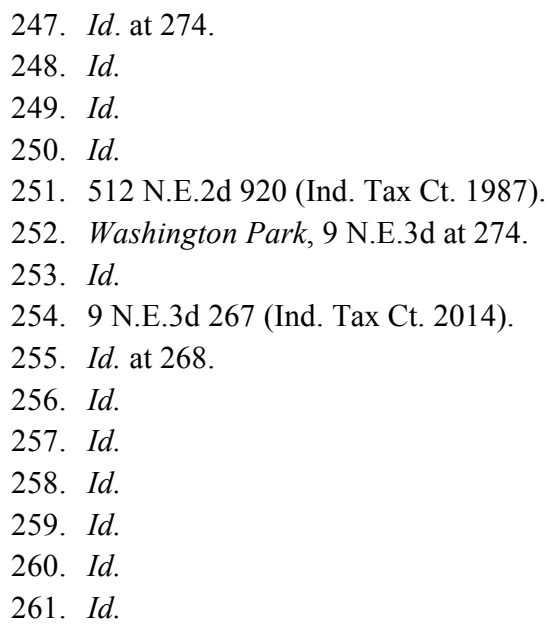


jurisdiction to rule on the injunction because the words "will raise" in Ind. Code section 33-26-6-2(b)(1) did not mean injunctive relief could be granted before the original tax appeal had been initiated. ${ }^{262}$

Ind. Code section 33-26-3 confers upon the Indiana Tax Court exclusive jurisdiction over "original tax appeals." 263 An original tax appeal is a case that arises through Indiana's tax laws and is an initial appeal of a final determination of either the Indiana Department of State Revenue or the IBTR. ${ }^{264}$ Thus, for the Indiana Tax Court to possess subject matter jurisdiction over a case, two requirements must be met: (1) the case must arise through Indiana's tax laws, and (2) the case must appeal a final determination of either the Department or the IBTR. ${ }^{265}$

Because West Ohio filed an injunction petition, but had not filed an original tax appeal, the Indiana Tax Court determined that the Indiana Tax Court did not have subject matter jurisdiction. ${ }^{266}$

6. Hamilton County Assessor v. SPD Realty, LLC. ${ }^{267}$ - In January 2009, SPD filed an Application for a Property Tax Exemption with the Hamilton County PTABOA, requesting a charitable purposes exemption for the 2009 tax year. ${ }^{268}$ The PTABOA denied SPD's application, and SPD appealed to the IBTR for an administrative hearing. ${ }^{269}$ The hearing before the IBTR resulted in a determination to grant the SPD exemption. ${ }^{270}$ Therefore, the Assessor initiated an original tax appeal. ${ }^{271}$

Thereafter, the IBTR determined a charitable purpose through Ind. Code section 6-1.1-10-16, because SPD was formed for the sole purpose of acquiring and renting the subject property to a nonprofit corporation. ${ }^{272}$ However, Ind. Code section 6-1.1-10-36.3(a) clearly required that a property be used or occupied for charitable purposes for more than fifty percent of the time that the property was actually used or occupied during the tax year. ${ }^{273}$ Because the property was used $100 \%$ of the time for charitable purposes when occupied, the Indiana Tax Court determined that the property was indeed predominately used for charitable purposes. ${ }^{274}$

7. McKeeman v. Steuben County Assessor. ${ }^{275}$-The McKeemans owned

262. Id. at 269.

263. IND. CODE $\S \S 33-26-3-1,-3$ (2014).

264. IND. CODE $\S 33-26-3-1$ (2014).

265. West Ohio, 9 N.E.3d at 269.

266. Id.

267. 9 N.E.3d 773 (Ind. Tax Ct. 2014).

268. Id. at 774 .

269. $I d$.

270. $I d$.

271. Id. at 775 .

272. Id. at 776-78.

273. Id.

274. $I d$.

275. 10 N.E.3d 612 (Ind. Tax Ct. 2014). 
residential property in Indiana. ${ }^{276}$ During the 2006 tax year, the property was assessed at $\$ 489,000{ }^{277}$ The McKeemans believed their land assessment was too high, and thus sought review with the Steuben County PTABOA, and then, with the IBTR. ${ }^{278}$ On March 11, 2011, the IBTR issued a final determination upholding the PTABOA's assessment in its entirety, and then, on April 22, 2011, the McKeemans appealed the matter to the Indiana Tax Court. ${ }^{279}$

A party seeking to overturn a final determination of the IBTR bears the burden to demonstrate that the determination is invalid. ${ }^{280}$ Consequently, such party must demonstrate that the IBTR's determination was arbitrary, capricious, an abuse of discretion, not in accordance with the law, or unsupported by substantial evidence. ${ }^{281}$ Therefore, the McKeemans first contended that the IBTR erred in disregarding the McKeemans' claim concerning the establishment of their neighborhood. ${ }^{282}$ They also contend that the IBTR erred in rejecting their base rate claim and lastly, they argued that the IBTR erred in concluding the sales comparison analysis lacked probative value. ${ }^{283}$

Nonetheless, the Indiana Tax Court determined that the arguments were not persuasive. ${ }^{284}$ The Indiana Tax Court determined that even if the IBTR had relied on an Assessor's mistake, that alone would not warrant a reversal of the IBTR's final determination. ${ }^{285}$ Indeed, the IBTR's final determination explained that the argument lacked probative value for reasons unrelated to the Assessor's erroneous claim. ${ }^{286}$ Moreover, the IBTR explained that the McKeemans' valuations also failed to demonstrate that their assessment was too high. ${ }^{287}$ Consequently, the McKeemans did not demonstrate that the IBTR erred in concluding that the sales comparison analysis lacked probative value. ${ }^{288}$

Here, the Indiana Tax Court held that differences in road access, size, and use type did not establish that an assessor ignored Indiana's real property assessment guidelines. ${ }^{289}$ Because the record did not disclose what properties were used in developing the base rate, owners of residential property did not show error regarding the base rate applied to their land. ${ }^{290}$ Additionally, the IBTR did not err in concluding that the owners' sales comparison analysis lacked

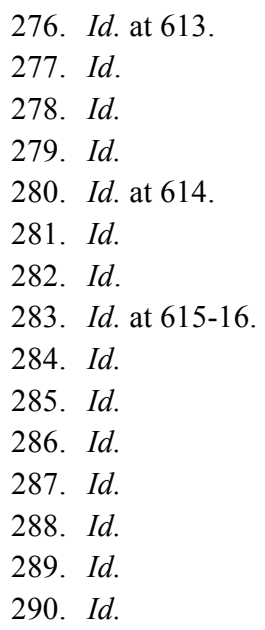


probative value because even if the IBTR relied on a mistaken claim by the assessor, that probative value was lacking for other reasons unrelated to the assessor's erroneous claim to the Indiana Tax Court. ${ }^{291}$

8. Idris v. Marion County Assessor. ${ }^{292}$-Idris and Kamenova, co-own a 2135 square foot condominium unit in downtown Indianapolis. ${ }^{293}$ The unit is in a sixstory, mixed-use building. ${ }^{294}$ For the 2006 tax year, the condominium was assessed at $\$ 395,900 .{ }^{295}$ Idris believed the assessment was too high and sought review first with the Marion County PTABOA and then with the IBTR. ${ }^{296}$ The IBTR held a hearing during which Kamenova argued the assessment should be reduced to $\$ 270,000$ because Kamenova was forced to endure excessive noise, foul odors, and persistent crime. ${ }^{297}$ Kamenova also claimed that the assessments of three other condominium units within the building demonstrated that Kamenova's unit was over-assessed. ${ }^{298}$ To support this claim, Kamenova presented several photographs of the building, a fire incident report, a newspaper article, a surveillance printout, and the Marion County Tax Reports and real estate listings for those units, which indicated that the condominium units ranged from between 1900 to 2200 square feet and were assessed at approximately $\$ 132,000$ to $\$ 152,000$ for the 2006 tax year. ${ }^{299}$ On June 20, 2011, the IBTR issued a final determination in which it declined to reduce the assessment. ${ }^{300}$

On appeal, Idris argued that the IBTR's final determination must be reversed for three reasons. ${ }^{301}$ First, for abuse in discretion in finding that Kamenova failed to establish that their property was entitled to an obsolescence adjustment, and second, for abuse in discretion in determining that the assessments of the three other units in their building failed to show that their property was over-assessed, and third, Idris claimed that the IBTR erred in upholding their assessment given the Assessor's improper use of the "one unit multiple units" classification. ${ }^{302}$

The IBTR held that they were not entitled to an obsolescence adjustment because even assuming that Kamenova established that the undesirable view, odor problems, excessive noise, and crime issues had diminished the value of their property, Kamenova did not present evidence that showed what a more accurate assessment would be. ${ }^{303}$ As the IBTR explained, such a comparison falls short of establishing comparability for purposes of an assessment

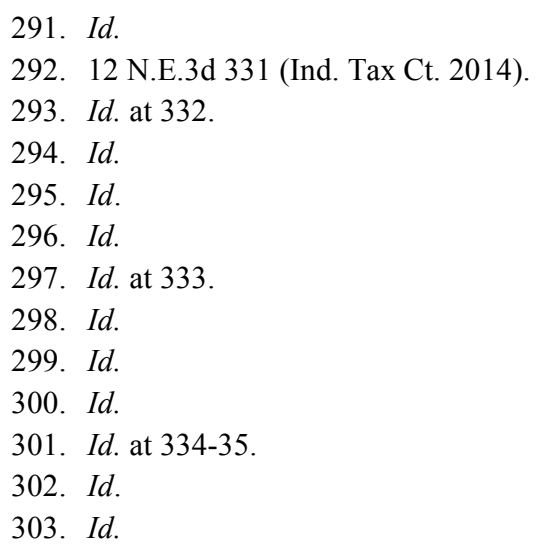


reduction. ${ }^{304}$

The Indiana Tax Court found that the IBTR abused its discretion if the IBTR's final determination was clearly against the logic and effect of the facts and circumstances before the IBTR or if the IBTR misinterprets the law. ${ }^{305}$ Here, the Indiana Tax Court held that the owner failed to show that the property at issue was entitled to an obsolescence adjustment because there was no quantification or any other evidence to substantiate the claim. ${ }^{306}$ Furthermore, Kamenova did not describe Kamenova's unit's characteristics or explain how any similarities or differences between Kamenova's unit and the allegedly comparable units affected the value. ${ }^{307}$ Therefore, the Indiana Tax Court did not reverse the IBTR's final determination. ${ }^{308}$

9. Housing Partnerships, Inc. v. Owens. ${ }^{309}$ - In February 2006, Housing Partnerships filed an application for Property Tax Exemption on each of its rental properties and its administrative office. ${ }^{310}$ The applications claimed the properties were entitled to the charitable purposes exemption which is set forth in Ind. Code section 6-1.1-10-16, because they were used to provide housing to low-income individuals and families. ${ }^{311}$ On March 13, 2007, the Bartholomew County PTABOA denied the applications. ${ }^{312}$

Thereafter, Housing Partnerships subsequently appealed to the IBTR and the IBTR issued a final determination affirming the PTABOA's exemption denial because Housing Partnerships' evidence failed to establish a prima facie case that the subject properties were entitled to the charitable purposes exemption. ${ }^{313}$ The IBTR's final determination also stated that Housing Partnerships had received a substantial amount of money through federal grants, but that Housing Partnerships did not explain what, if any, terms and conditions were attached to the providing of such grants. ${ }^{314}$ Therefore, the IBTR held that it was not proper for the IBTR to grant the requested exemption. ${ }^{315}$

Based on these facts, the Indiana Tax Court held that the IBTR's decision that a not-for-profit corporation's rental properties did not qualify for the charitable purposes exemption of Ind. Code section 6-1.1-10-16 and that the decision of the IBTR's was not arbitrary, capricious, or an abuse of discretion. ${ }^{316}$ Further, the Indiana Tax Court held that the fact that Housing Partnerships

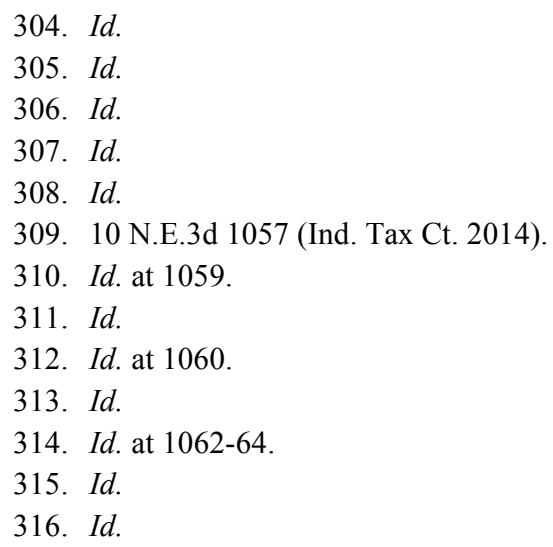


charged low-income individuals below-market rents for its apartments and that Housing Partnerships provided free services to its tenants was not enough to demonstrate that the property was used for a charitable purpose. ${ }^{317}$ Specifically, Housing Partnerships still had to provide evidence that Housing Partnerships had relieved the government of an expense that the government would have otherwise borne. ${ }^{318}$ That is, no probative evidence was offered to the IBTR for the IBTR to consider in determining whether or not Housing Partnerships relieved the government of an expense which the government would otherwise have borne and no evidence was provided to the IBTR as to whether or not the government, through its federal grants, was still bearing the expense. ${ }^{319}$ Therefore, Housing Partnerships' petition to the Indiana Tax Court was denied. ${ }^{320}$

10. Howard County Assessor v. Kokomo Mall, LLC. ${ }^{321}$ - Believing that the assessments of three parcels were too high, Kokomo Mall appealed, first to the Howard County PTABOA and then to the IBTR. ${ }^{322}$ At the IBTR hearing, Kokomo Mall presented a summary appraisal report, completed in conformance with the Uniform Standards of Professional Appraisal Practice ("USPAP"), which valued Parcel No. 20 at $\$ 4,960,000$ for 2007, all three parcels at $\$ 6,080,000$ for 2008 , and all three parcels at $\$ 3,990,000$ for $2009 .{ }^{323}$ Kokomo Mall also presented testimony from Sara Coers, who prepared the Appraisal. ${ }^{324}$ Coers explained that Coers arrived at these values by adding her income approach valuations for all three parcels ${ }^{325}$ to the corresponding movie theater assessments. $^{326}$

The Assessor contended that the IBTR erred in finding that Kokomo Mall made a prima facie case, because the IBTR did not adequately scrutinize Kokomo Mall's unreliable evidence. ${ }^{327}$ Instead, the IBTR simply deferred to Coers' testimony and adopted Coer's appraisal even though the appraisal did not comply with USPAP. ${ }^{328}$ However, it is well-established that when the Indiana Tax Court reviews a final determination of the IBTR, it may not reweigh the evidence nor judge the credibility of the witnesses. ${ }^{329}$ Thus, the Indiana Tax

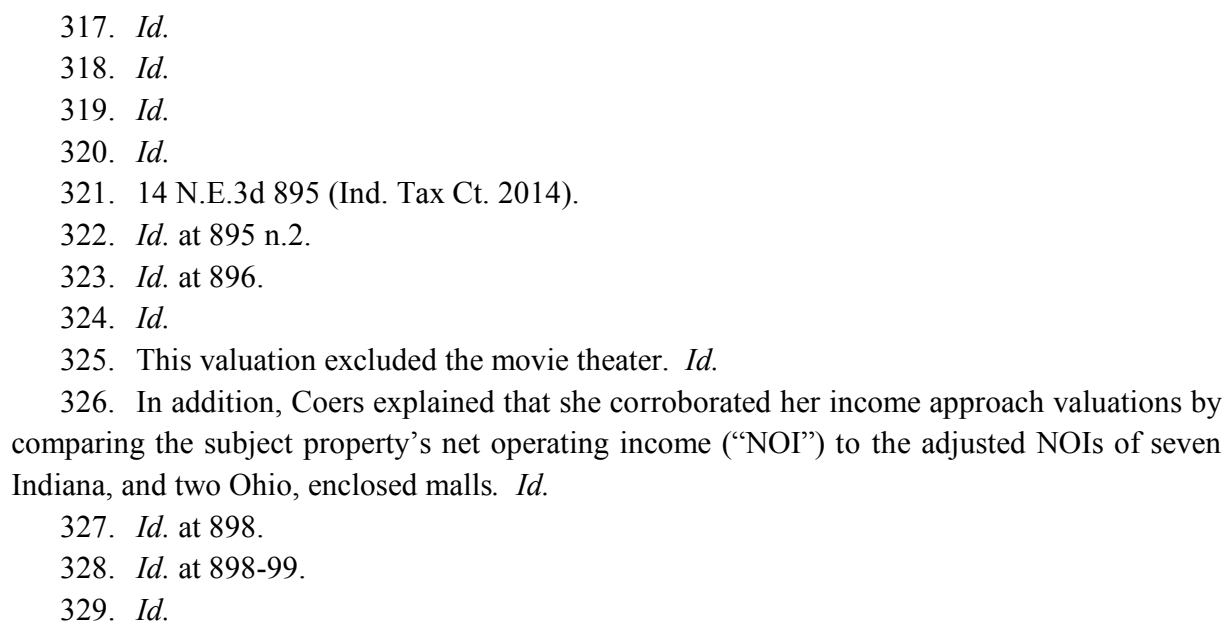


Court is limited to what it can do when reviewing evidence on appeal. ${ }^{330}$ Consequently, the Assessor did not show the IBTR's determination must be reversed on this basis. ${ }^{331}$

Next, the Assessor claimed that policy should be changed because the policy eviscerates the IBTR's discretion to assess the reliability of appraisals and more improperly shifts the burden of proof to assessing officials, effectively compelling assessing officials to hire their own appraisers despite the prevailing financial constraints. ${ }^{332}$ Nevertheless, the Indiana Tax Court also determined that such an argument is unpersuasive, and therefore, the Indiana Tax Court held that a taxpayer may rebut the correctness of an assessment by introducing relevant market data, or any other data compiled in accordance with generally accepted appraisal principles. ${ }^{333}$ Accordingly, the Indiana Tax Court did not reverse the IBTR's final determination on this basis. ${ }^{334}$

11. Indianapolis Racquet Club, Inc. v. Marion County Assessor. ${ }^{335}$ Believing their real property assessments were too high, the Indianapolis Racquet Club ("Racquet Club") filed three petitions for review with the Marion County PTABOA. ${ }^{336}$ When the Racquet Club was not successful at that level, the Racquet Club filed three petitions for review with the IBTR. ${ }^{337}$ The IBTR consolidated the petitions and held an administrative hearing, which resulted in a final determination upholding all of the three assessments. ${ }^{338}$ In its final determination, the IBTR explained that the Racquet Club failed to establish a prima facie case that its parcels were over-valued. ${ }^{339}$ Subsequently, the Racquet Club initiated three original tax appeals with the Indiana Tax Court. ${ }^{340}$

On appeal, the Racquet Club argued that the IBTR's final determination must be reversed because it was not supported by the evidence or in accordance with the law. ${ }^{341}$ But based on the evidence presented, the IBTR did not err in determining the Racquet Club did not establish a prima facie case. ${ }^{342}$ Thereafter, the Indiana Tax Court stated that the Racquet Club failed to establish a prima facie case that the parcels were overvalued or that the land assessments were not "uniform and equal." ${ }^{433}$ Simply looking to other assessments that were subject to different land conditions did not, on its face, demonstrate that the Racquet

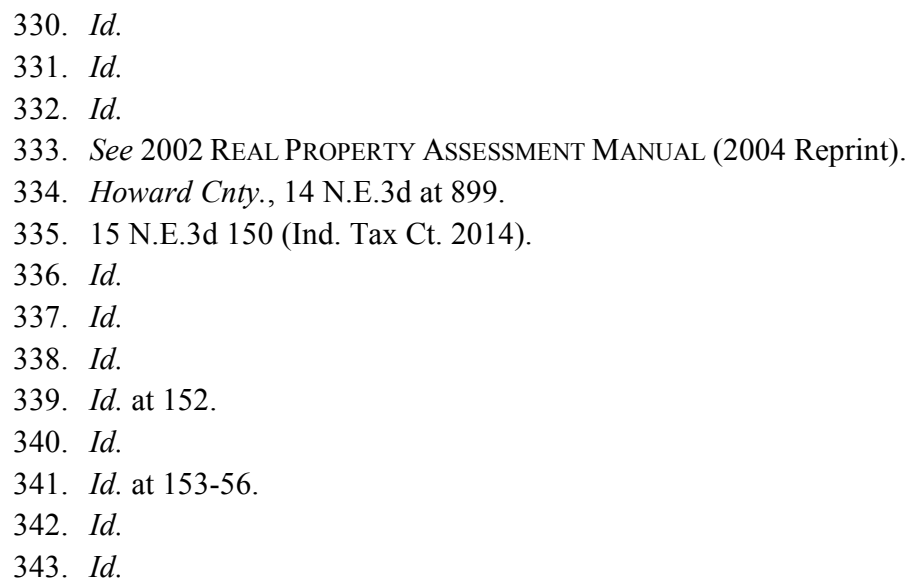


Club's land assessments were incorrect. The Racquet Club did not quantify the negative impact of an inconsistent use. ${ }^{344}$

Moreover, with respect to the value of its land and by asserting assessments were not uniform and equal simply because the land at three other tennis clubs, none of which were even in the same township, ${ }^{345}$ were assessed at different values - none of which were in the same township as the Racquet Club was located - was not sufficient to show a lack of uniformity and equality, and thus unpersuasive. ${ }^{346}$ Indeed, the Racquet Club needed to provide some sort of explanation or analysis as to what factors made the value of the land at those properties comparable to its own. ${ }^{347}$ Likewise, if there were any distinguishing characteristics that would affect the land values, the Racquet Club needed to account for those characteristics by making adjustments and statements that such properties "are similar." 348 However, the IBTR did err in denying relief insofar there was a copy of this parcel's record card that displayed an error. ${ }^{349}$ Accordingly, the Indiana Tax Court remanded this issue to the IBTR so that the IBTR could instruct the Assessor to correct the record card so that the parcel's square footage and acreage are consistent. ${ }^{350}$

12. Housing Partnerships v. Owens. ${ }^{351}$ - On June 4, 2014, the Indiana Tax Court issued an opinion in Housing Partnerships, Inc. v. Tom Owens, Bartholomew County Assessor, holding that Housing Partnerships failed to show that its rental properties qualified for the charitable purposes exemption. ${ }^{352}$ Housing Partnerships requested the Indiana Tax Court to reverse that decision. ${ }^{353}$ However, the Indiana Tax Court denied the request. ${ }^{354}$

In the petition for rehearing, Housing Partnerships acknowledged that eligibility for the charitable purposes exemption requires a showing that through Indiana Constitution article. 10, section 1, Housing Partnerships owned, occupied, and used its property for purposes that relieve human want by acts which differ from the everyday activities of man and show that its activities benefit the public sufficiently to justify the loss of tax revenue. ${ }^{355}$ However, Housing Partnerships asked for a reversal, claiming the Indiana Tax Court had not only failed to recognize the substantial evidence that demonstrated its activities relieve the government of a burden that the government would otherwise bear, but also that the Indiana Tax Court misconstrued the holding in

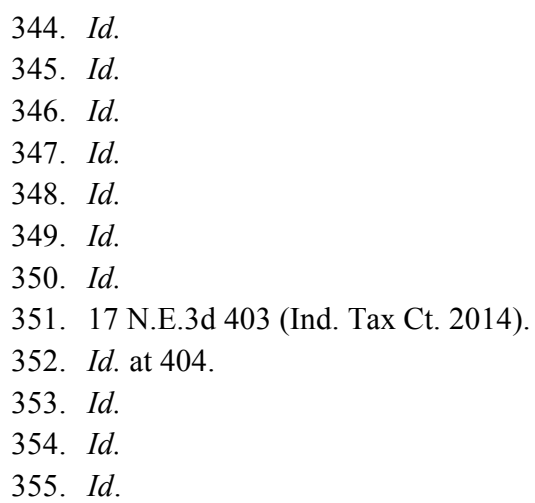


Jamestown Homes of Mishawaka. ${ }^{356}$

Because Housing Partnerships advanced the same rationale as grounds to reverse the IBTR's final determination, the Indiana Tax Court clarified why Housing Partnerships did not merit the exemption. ${ }^{357}$ The provision of lowincome housing is not per se a charitable purpose. ${ }^{358}$ Good and noble deeds alone do not satisfy the requirements for a charitable purposes exemption. ${ }^{359}$ Evidence is still required to demonstrate that the good deeds relieve the government of a cost that the government would otherwise bear. ${ }^{360}$ While Housing Partnerships stated good works, it made only conclusory statements about how those good works lessened government's financial burdens. ${ }^{361}$ Both times, ${ }^{362}$ Housing Partnerships used only conclusory statements to link the evidence of its good deeds to how its good deeds lessen governmental burdens. ${ }^{363}$ This is insufficient to show that it is entitled to a charitable purposes exemption. Accordingly, the Indiana Tax Court granted a rehearing for the limited purpose of providing the above clarification and otherwise denied Housing Partnerships' Petition for Rehearing. ${ }^{364}$

\section{B. Local Tax}

1. Van Buren Township v. Department of Local Government Finance. ${ }^{365}$ - In 2010, Van Buren Township, Madison County, and Boone Township, Madison County (the "Townships"), entered into an agreement that created the Summitville Fire Protection Territory. ${ }^{366}$ The Townships needed the DLGF's approval, to fund the venture, in order to impose a tax levy within their respective jurisdictions. ${ }^{367}$ However, because the Townships had not given appropriate notice, which is required by Ind. Code section 36-8-19-6, the DLGF denied the levy request. ${ }^{368}$

The Townships argued that the failure of their fire protection territory notices was cured by the fact that the notices were published on the same day in the same paper and when read together contained the necessary information. ${ }^{369}$ However, the Indiana Tax Court stated that the administrative record was devoid of any

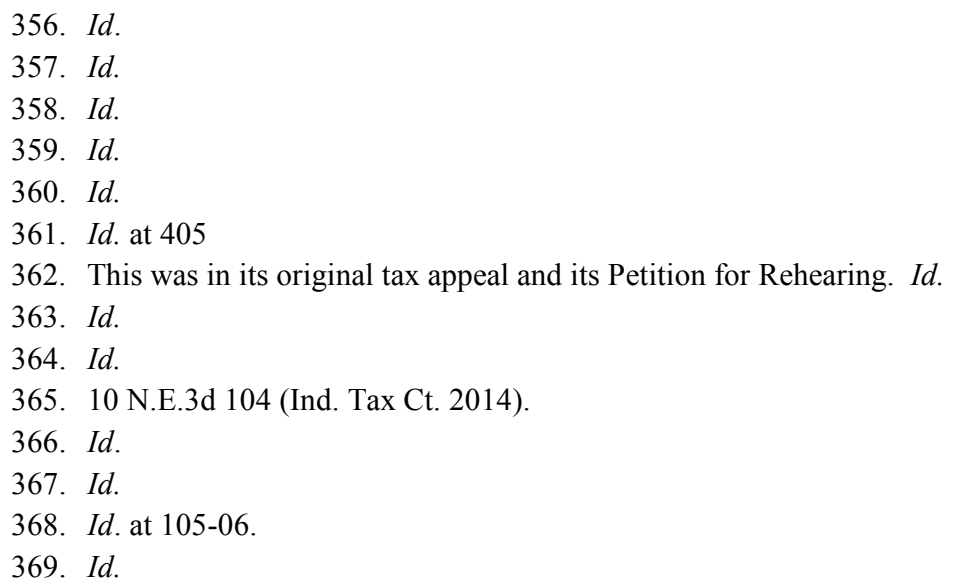


evidence that demonstrated that the two notices were in fact published on the same days in the same newspaper. ${ }^{370}$ The Townships admitted that Van Buren Township's notice did not comply with Ind. Code section 36-8-19-6(b). ${ }^{371}$ Specifically, the Townships admitted that the Van Buren Township notice failed to designate: (1) which Township was the fire territory's provider unit and which Township was the participating unit; (2) the location where the public could inspect the proposed resolution creating the fire territory; and (3) who could be contacted for further information and how. ${ }^{372}$ Moreover, the Townships admitted that the Van Buren Township notice erroneously included Duck Township. ${ }^{373}$ Even so, the Townships argued on appeal that the DLGF's final determination denying their levy request was improper because a reasonable person would not have been misled by the Van Buren Township notice's defects. ${ }^{374}$

However, the Indiana Tax Court did not determine whether or not there was any merit to the Townships' arguments because the administrative record in this case was completely devoid of any evidence that demonstrated that the two notices were in fact published on the same days in the same newspaper. ${ }^{375}$ Accordingly, the Indiana Tax Court did not find the DLGF's final determination to be improper, and thus, the Townships' request for relief was denied.

2. Speedway Public Library v. Indiana Department of Local Government Finance. ${ }^{376}$ - The DLGF issued a notice stating that the DLGF could not approve the Library's 2011 budget because no notice complying with Ind. Code section 6-1.1-17-3 had been provided to the public about the Town Council's September adoption meeting. ${ }^{377}$ As a result, the DLGF reinstituted the appropriations and levies associated with the Library's 2010 budget. ${ }^{378}$

On appeal by the Library, the Indiana Tax Court held that there was no merit to the Library's argument that Ind. Code section 6-1.1-17-3 did not require a public notice of a Town Council budget meeting. ${ }^{379}$ Moreover, as to the extent that the Library filed its budget with the town clerk through Ind. Code section 363-6-9(b), the statute applied to the Indianapolis-Marion County Public Library and not to the matter at issue here. ${ }^{380}$ The law in the matter before the Indiana Tax Court instructed the Town Council to review "and" adopt a final budget, not to review "or" adopt a budget. ${ }^{381}$ Also, Ind. Code section 6-1.1-17-20(c) required the Town Council to conduct a hearing on the Library's proposed budget and tax

370. Id.

371. $I d$.

372. Id.

373. $I d$.

374. $I d$.

375. Id. at 106 .

376. 12 N.E.3d 996 (Ind. Tax Ct. 2014).

377. Id. at 997.

378. Id.

379. Id. at 998-1000.

380. Id.

381. Id. 
rates, which in turn, required notice through Ind. Code section 6-1.1-17-3(a). ${ }^{382}$ Therefore, because the Town Council was required to provide the public notice of the Town Council's meeting on the Library's budget, but it did not do so, and therefore, the Town Council did not satisfy the notice requirement. ${ }^{383}$ More specifically, the Town Council was required to provide the public with notice of its September 13th meeting. ${ }^{384}$ Thus, the fact that the Library provided notice of its August 4th hearing and of its August 17th meeting missed the point. ${ }^{385}$ Furthermore, the record evidence did not show notice was provided for the September 13th meeting nor did it show that the agenda for that meeting was posted. ${ }^{386}$ Thus, the Indiana Tax Court affirmed the DLGF, finding that the prior hearing and meeting did not satisfy such notice requirement. ${ }^{387}$

3. Clark County v. Indiana Department of Local Government Finance. ${ }^{388}$ - In 2007, the Town Council determined it would not levy the maximum amount of property taxes permitted by statute for the 2008 budget year because the Town Council had nearly $\$ 4$ million in a rainy day fund. ${ }^{389}$ Thus, the Town Council approved a property tax levy for $\$ 2.7$ million less than what was statutorily allowed in 2008. ${ }^{390}$ But by 2010, Clark County had depleted the cash reserves in its rainy day fund. ${ }^{391}$ Thus, Clark County attempted to reclaim the property tax revenue by petitioning the DLGF for permission to impose an excess property tax levy in the amount of $\$ 7,206,383 .{ }^{392}$ Clark County's petition stated that the DLGF could approve the levy appeal because the Town Council made a "data error," which was correctable through Ind. Code section 6-1.1-18.5-14..$^{393}$

On appeal, Clark County provided three reasons why the DLGF's final determination was invalid. ${ }^{394}$ First, Clark County argued that the DLGF abused its discretion by arbitrarily and capriciously determining that the Town Council did not make a data error. ${ }^{395}$ Second, Clark County argued that the DLGF contravened the law when it failed to retroactively apply the 2011 statutory amendment that eliminated the "use it or lose it" provision from the formula. ${ }^{396}$ Third, Clark County argued that the DLGF violated Clark County's due process

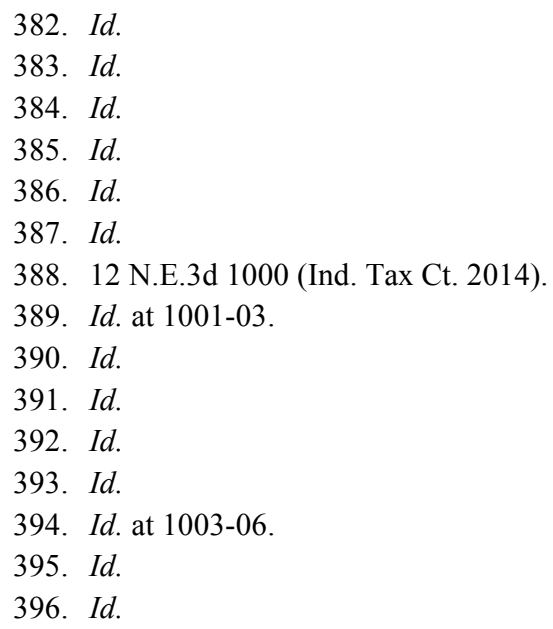


rights. $^{397}$

However, the Indiana Tax Court determined that there was no record evidence to indicate that there was an objective error in the Town Council's data when its decision was made to forego the maximum levy allowable for $2008 .^{398}$ The Town Council approved a property tax levy for $\$ 2.7$ million less than what was statutorily allowed in 2008, which was not an "error in data," ${ }^{\prime 399}$ nor was it even an error in interpreting data. ${ }^{400}$ Instead, it was simply a failure on the part of the Town Council to plan for budgetary contingencies. ${ }^{401}$ Consequently, the Indiana Tax Court determined not to reverse the DLGF's final determination because the Indiana Tax Court determined that Ind. Code section 6-1.1-18.5-14 is for the correction of an objective error only and not for a failure on the part of the Town Council to plan for budgetary contingencies. ${ }^{402}$ The 2011 amendment eliminating the "use it or lose it" ${ }^{403}$ provision of Ind. Code section 6-1.1-18.5-3 unambiguously provided that the Town Council was not entitled to retroactive effect. $^{404}$ Therefore, the Indiana Tax Court determined the Town Council did not make a data error which was correctable through Ind. Code section 6-1.1-18.5-14, when the Town Council approved its 2008 property tax levy for $\$ 2.7$ million less than what was statutorily permitted. ${ }^{405}$

4. Gary Community School Corp. v. Indiana Department of Local Government Finance. ${ }^{406}$ - On April 19, 2011, the Gary Community School Corporation ("School Corporation") filed an original tax appeal, claiming that the DLGF erred in reducing its exempt debt service fund levy for the 2011 budget year. ${ }^{407}$ The DLGF moved to strike the Appendix attached to the School Corporation's brief on the grounds that its three exhibits were not part of the certified administrative record. ${ }^{408}$ Subsequently, the School Corporation filed a brief in opposition to which it attached another exhibit, a two-page letter from the School Corporation to the DLGF. ${ }^{409}$

On appeal, this matter concerned the DLGF's motion to strike four exhibits that were submitted to support the School Corporation's appeal. ${ }^{410}$ However, Indiana Tax Court denied the motion in part and granted it in part, because nothing within the record or the arguments indicated that the exhibits were

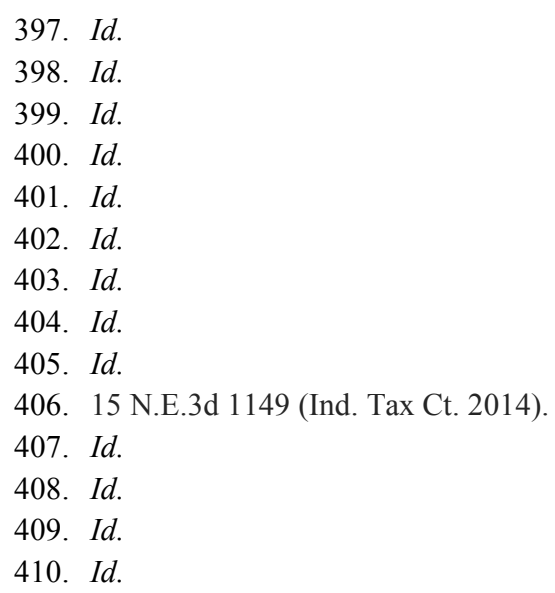


submitted to the DLGF during the administrative proceedings. ${ }^{411}$ Accordingly, the Indiana Tax Court was not persuaded that the exhibits in the Appendix were properly before the Indiana Tax Court. ${ }^{412}$ Furthermore, the record failed to reveal what communications or procedures occurred during the protest, nor identified the documents that DLGF considered. ${ }^{413}$ This sparse record would suggest that the School Corporation did not present a single written item to the DLGF with respect to the School Corporation's protest. ${ }^{414}$ Based on the totality of the evidence, the Indiana Tax Court held that the March letter should have been in the record and, as such, it was properly before the Indiana Tax Court. ${ }^{415}$

Moreover, because the Indiana Tax Court could only consider the evidence presented to the DLGF during the administrative process, the DLGF was entitled to strike certain exhibits. ${ }^{416}$ Additionally, the content of a letter, which was written on School Corporation letterhead and dated the same day when the School Corporation filed its protest, provided the DLGF with an additional rationale in support of the School Corporation's requested levy, because this indicated that the letter was part of the School Corporation's protest, and therefore, the letter should have been in the record. ${ }^{417}$

5. Gary Community School Corp. v. Indiana Department of Local Government Finance. ${ }^{418}$ - On March 23, 2011, the DLGF reduced the School Corporation's exempt debt service fund levy by removing all the amounts that related to the payment of the rental obligations. ${ }^{419}$ The DLGF explained it had done so because there was no indication that the School Corporation had used an exempt debt service fund levy to pay its rental obligations in the past. ${ }^{420}$ In March, 2011, the School Corporation filed a written protest with the DLGF which was denied without explanation. Therefore, the School Corporation initiated an original tax appeal. ${ }^{421}$

On appeal, the School Corporation asked the Indiana Tax Court to reverse the DLGF's decision, because the statutory framework for reviewing these levies limited the DLGF's authority to considering whether or not that fund alone was sufficient to pay the rental obligations. ${ }^{422}$ The DLGF, on the other hand, maintained it properly considered the amounts available to the School Corporation's general fund because no statute prohibited it from doing so. ${ }^{423}$

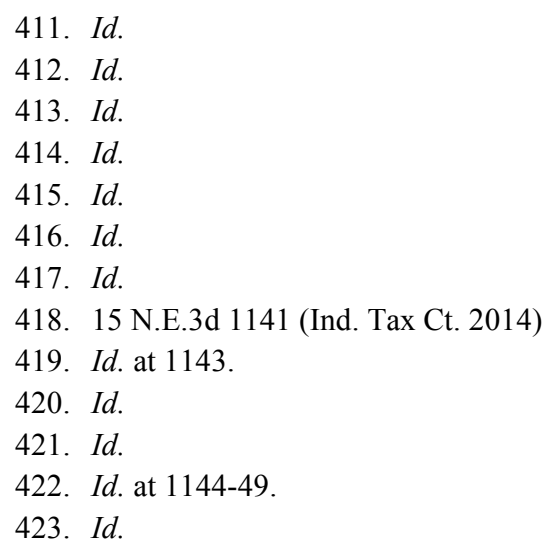


Further, the DLGF explained that given its expertise and overall fiscal responsibility, the GA could have intended to consider other funding sources in its budget reviews. ${ }^{424}$ However, because of the absence of this provision, the Indiana Tax Court determined that the Indiana Tax Court would not imply that the DLGF had the authority to do so. ${ }^{425}$ Indeed, if the GA had intended for the DLGF to consider other funding sources, it could have affirmatively stated so, but it did not. ${ }^{426}$ Accordingly, the Indiana Tax Court did not construe the lack of a statutory prohibition as authorizing the DLGF to consider other funding sources without express language to that effect. ${ }^{427}$

Thus, the DLGF exceeded its statutory authority in reducing the School Corporation's exempt debt service fund levy, as the absence of a statutory prohibition did not provide the DLGF with the authority to consider the amounts available from the School Corporation's general fund. ${ }^{428}$ Further, even if the DLGF's consideration of other funding sources had been proper, the DLGF offered no evidence to support the finding that the School Corporation had sufficient funds in its general fund to cover its rental obligations. ${ }^{429}$

6. City of Greenfield v. Indiana Department of Local Government Finance. ${ }^{430}$ - On October 17, 2011, the DLGF issued a final determination reducing the Greenfield Fire Protection Territory's ("Territory") general fund levy from $\$ 2,345,015$ to $\$ 2,060,260 .{ }^{431}$ In so doing, the DLGF effectively eliminated the Territory's use of a uniform tax rate by setting the City of Greenfield's maximum general fund levy and Center Township's maximum general fund levy. ${ }^{432}$ However, the DLGF did not adjust the tax rate or levy for the equipment replacement fund. ${ }^{433}$ Thus on November 16, 2011, the City of Greenfield and the Territory initiated an original tax appeal with the Indiana Tax Court. ${ }^{434}$

On appeal, the City of Greenfield and the Territory contended that the DLGF's final determination must be reversed because it was arbitrary and capricious and not supported by evidence. ${ }^{435}$ In addition, the City of Greenfield and the Territory claimed that the DLGF's final determination was invalid because Public Law 172-2011, section 164 violates Indiana's Constitution by contravening the special legislation provisions of article $4 .{ }^{436}$

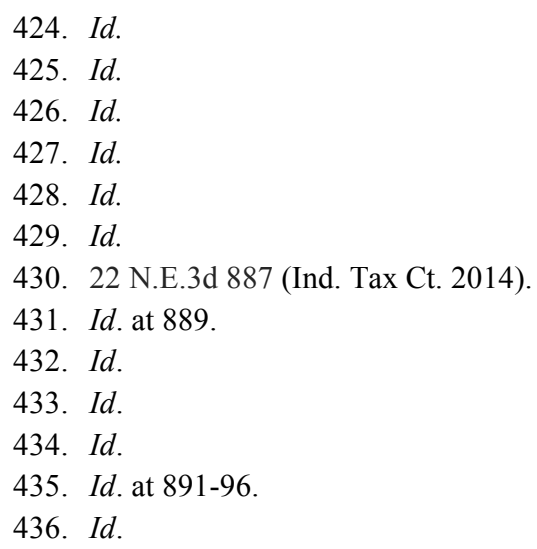


Thereafter, the Indiana Tax Court examined whether there were inherent characteristics of the affected class that could justify special legislation. ${ }^{437}$ When doing so, the Indiana Tax Court must consider two factors. ${ }^{438}$ First, the Indiana Tax Court must determine if there is something about the class that makes it unique; and, second, if such uniqueness exists, then whether or not the uniqueness justifies the differential treatment. ${ }^{439}$

Ultimately, the Indiana Tax Court determined that the provisions indicated that Public Law 172-2011, section 164 could have been written to apply throughout the state because neither the Territory nor the circumstances surrounding its establishment are unique. ${ }^{440}$ Thus, Public Law 172-2011, section 164 did in fact contravene the special legislation provisions in article 4 of the Indiana Constitution. ${ }^{441}$ Accordingly, the DLGF's determination was invalid. ${ }^{442}$

\section{Sales and Use Tax}

1. Tannins of Indianapolis, LLC v. Indiana Department of State Revenue. ${ }^{443}$ - On October 9, 2012, the Indiana Department of State Revenue completed an audit of Tannins, and on November 13, 2012, the Department issued proposed assessments of use tax for each of the years plus interest. ${ }^{444}$ Thus, Tannins filed a written protest with the Department, claiming its purchases of the tasting cards were exempt from Indiana sales or use taxation. ${ }^{445}$ After conducting a hearing, the Department issued the Letter of Findings, which upheld the proposed assessments. ${ }^{446}$ Subsequently, Tannins filed an original tax appeal on March 22, 2013, and on January 10, 2014, the Indiana Tax Court held a trial and heard oral argument on January 10, 2014. ${ }^{447}$

Tannins claimed that the purchase of tasting cards were exempt from sales and use tax through Ind. Code section 6-2.5-5-8(b) because Tannins resold the tasting cards to its customers. ${ }^{448}$ To support this position the CEO of Tannins testified that the cost of the cards was included in its cost of goods sold and such expense was factored in the sale price of the wine. ${ }^{449}$ However, the Indiana Tax

437. Id

438. Id. at 894 .

439. Id. at 894-96.

440. Id.

441. Id.

442. Id.

443. 6 N.E.3d 511 (Ind. Tax Ct. 2014).

444. Id. at 512 .

445. Id.

446. Id.

447. Id.

448. To support this position, the CEO of Tannins testified that the cost of the cards was included in its cost of goods sold and such expense was factored in the sale price of the wine. $I d$ at 513-14.

449. Id. 
Court explained that for a resale to exist, the buyer and seller must separately bargain for the property in exchange for the payment of consideration. ${ }^{450}$ The separately bargained-for requirement demonstrates that the exact item was actually resold, and not merely transferred by the retailer for another purpose. ${ }^{451}$

In this case, Tannins did not provide its customers with a receipt that separately identified a charge for the tasting cards or any other evidence to show a separately bargained for exchange, and the Indiana Tax Court held the cards were not exempt from use tax. ${ }^{452}$ Further, the separately bargained-for requirement is the standard against which a resale has been tested for decades, ${ }^{453}$ and Tannins did not present any legal authority or rationale to persuade the Indiana Tax Court that this was not the law. ${ }^{454}$ As such, Tannins failed to show that the cards were separately bargained for by its customers and that such cards did not change the usefulness of the separately bargained-for requirement. ${ }^{455}$ Thus, the Indiana Tax Court held the cards were not exempt from use tax through Ind. Code section 6-2.5-5-8(b) because the cards were not resold through Ind. Code section 6-2.5-5-8(b). ${ }^{456}$

2. Hoosier Roll Shop Services LLC v. Indiana Department of State Revenue. ${ }^{457}$ - Here, the Indiana Department of State Revenue completed an audit of Hoosier Roll, which showed that certain items were purchased without paying sales tax at the time of purchase and subsequently no use tax had been paid. ${ }^{458}$ Consequently, the Department issued a notice of Proposed Assessment to Hoosier Roll, and Hoosier Roll then protested the proposed assessments, claiming that the purchases at issue were exempt from Indiana sales and use taxation. ${ }^{459}$ An administrative hearing on the matter resulted in a Letter of Findings denying Hoosier Roll's protest. ${ }^{460}$ Subsequently, Hoosier Roll requested a rehearing, which the Department denied. ${ }^{461}$ Therefore, Hoosier Roll filed an original tax appeal with the Indiana Tax Court. ${ }^{462}$

On March 14, 2012, both Hoosier Roll and the Department filed motions for summary judgment. ${ }^{463}$ The Indiana Tax Court conducted a hearing on those motions on May 11, 2012, and, as a result, the Indiana Tax Court held that because substantial physical changes were made to the work rolls, that process

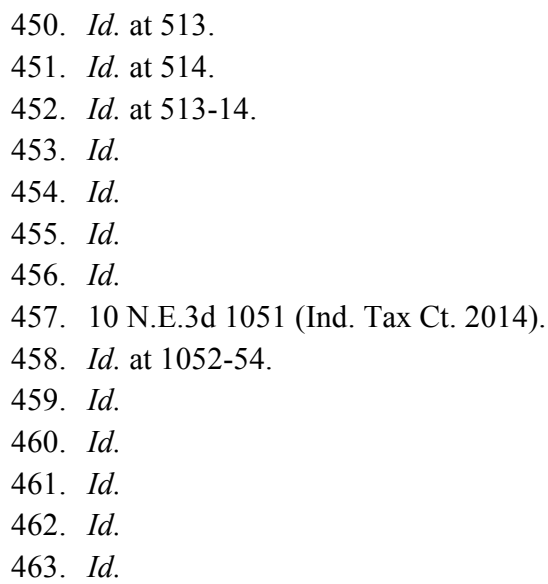


had indeed added value, and thus, was not work which was contemplated as normal to the work process. ${ }^{464}$ Therefore, the taxpayer was entitled to the exemptions from the sales and use taxes through Ind. Code section 6-2.5-5-3(b), section 6-2.5-5-4, and section 6-2.5-5-5.1(b). ${ }^{465}$

3. Lowe's Home Centers, LLC v. Indiana Department of State Revenue. ${ }^{466}$ In November of 2010, the Indiana Department of State Revenue completed an audit of Lowes, and during the course of the audit, the Department determined that instead of self-assessing and remitting use tax on construction materials furnished through the installation contracts, Lowes should have collected sales tax using the retail cost of the construction materials. ${ }^{467}$ As a result, the Department issued proposed sales tax assessments against Lowes, including penalties and interest. ${ }^{468}$

Lowes subsequently filed a protest with the Department and on June 28, 2011, the Department issued a Letter of Findings denying Lowes's protest. ${ }^{469}$ The Department again denied Lowes's protest in a Supplemental Letter of Findings, and therefore, Lowes initiated an original tax appeal with the Indiana Tax Court. ${ }^{470}$

The Department made two arguments to support its position. First, the Department argued that Lowes was not just a contractor, but rather, Lowes acted both as a retail merchant and a contractor. ${ }^{471}$ Thus, Lowes would bifurcate the installation contracts into separate "events" - a retail sale of tangible personal property subject to sales tax under Indiana Code section 6-2.5-4-1 and the subsequent, non-taxable service of adding that tangible personal property to a structure or facility. ${ }^{472}$ But in order for the Department to require Lowes to collect sales tax from its customers, Lowes must have both acquired the tangible personal property for the purpose of resale and then transferred that property to another person for consideration. ${ }^{473}$ The next argument was premised on the Department's belief that Lowes's installation contracts were time and material contracts and not lump sum contracts. ${ }^{474}$ As support for this argument, the Department cited to two more of its administrative regulations, 45 Ind. Admin. Code 2.2-3-9 and 45 Ind. Admin. Code 2.2-4-22. ${ }^{475}$ When a contractor enters into

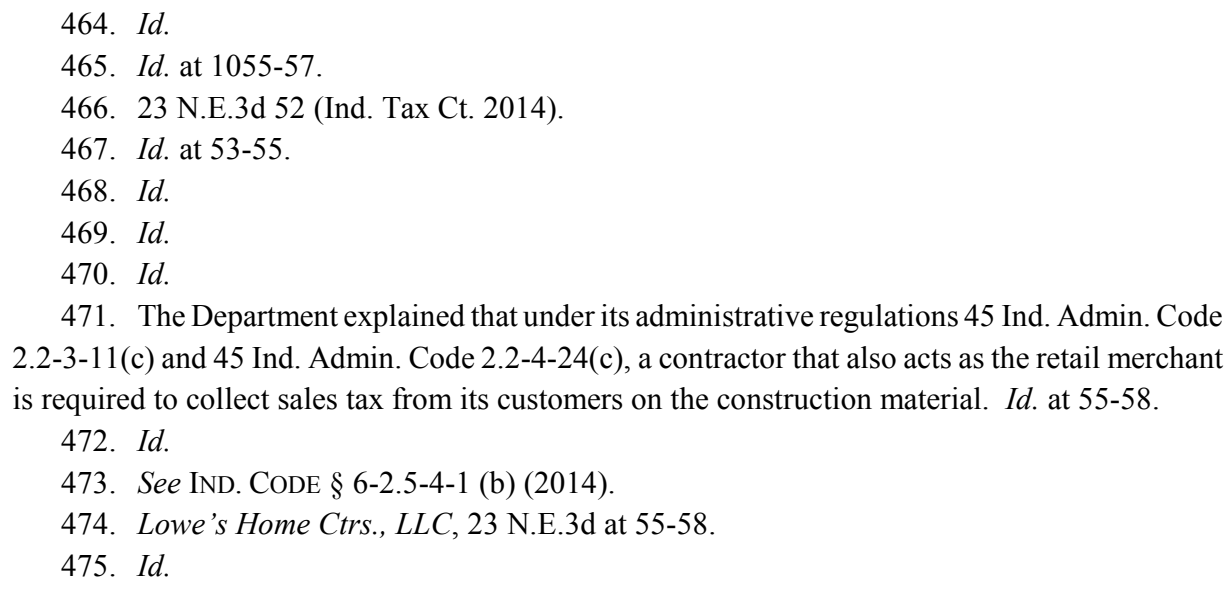


a time and material contract with a customer, the contractor owes no sales or use tax because the customer is liable for the sales tax on any construction material supplied thereunder. ${ }^{476}$

The Department claimed Lowes's installation contracts are "plainly" time and material contracts because such contracts identify a separate materials price from a separate price for labor charges. ${ }^{477}$ However, after reviewing the installation contracts in their entirety and finding the written expressions contained therein to be clear and unambiguous, the Indiana Tax Court concluded that Lowes and its customers intended and understood the installment contracts to be lump sum contracts. ${ }^{478}$ Thus, the Indiana Tax Court held for Lowes by concluding that the Department had created an artificial distinction between time and material contracts and lump sum contracts in its regulations in order to convert a contractor's use tax liability through Ind. Code section 6-2.5-3-2(c) into a sales tax liability on the materials' higher retail price. ${ }^{479}$

4. SAC Finance Inc. v. Indiana Department of State Revenue. ${ }^{480}$-SAC filed three claims with the Indiana Department of State Revenue seeking a refund of the Indiana sales tax that Superior Auto paid, but upon default such claims became uncollectible receivables to SAC. ${ }^{481}$ The Department issued a Letter of Findings, which denied SAC thirty percent of each refund claim. ${ }^{482}$ Therefore, SAC filed an original tax appeal challenging the Department's partial denial of the 2007 and 2008 refund claims. ${ }^{483}$

On February 11, 2011, SAC initiated another appeal challenging the Department's partial denial of its 2009 refund claim. ${ }^{484}$ The Indiana Tax Court subsequently consolidated the two appeals and on June 15, 2011, SAC filed a motion for summary judgment. ${ }^{485}$ The Department filed a cross-motion for summary judgment. ${ }^{486}$ On January 13, 2012, the Indiana Tax Court conducted a hearing on the parties' motions. ${ }^{487}$

SAC claimed that it was entitled to judgment as a matter of law because its use of the Market Discount Rules was proper. ${ }^{488}$ The Department contended, that SAC incorrectly used the Market Discount Rules, because those rules bypassed the mathematics of IRC section 166, were inapplicable according to IRC section $453 \mathrm{~B}$, and unavailable because SAC failed to designate evidence to show that it

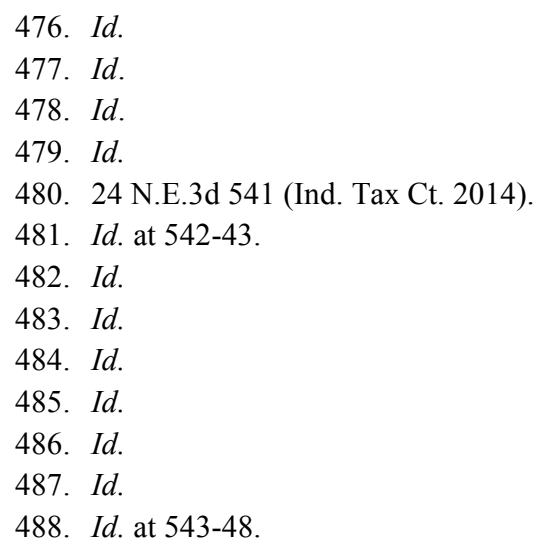


complied with certain procedural prerequisites. ${ }^{489}$

However, the Indiana Bad Debt Statute requires a retail merchant (or its assignee) to deduct the amount written off as uncollectible debt for federal tax purposes through IRC section 166 from its gross retail income. ${ }^{490}$ Accordingly, the amount written off through IRC section 166 is incorporated into the Indiana calculation solely as the computational starting point in determining Indiana's bad debt deduction. ${ }^{491}$ Specifically, subsection (d) requires a taxpayer to exclude amounts that reduce the original sales tax base ${ }^{492}$ from the difference between gross retail income and the amount of the federal bad debt. ${ }^{43}$

But, the Department contended that it properly removed market discount income from SAC's Indiana bad debt deduction because subsection (d) must treat market discount income in the same way it is treated for federal income tax purposes - as interest. ${ }^{494}$ Indiana, however, does not conform to the federal treatment of market discount income, and thus, the price SAC paid for the installment sale contracts is unrelated to the amount of sales tax paid to the Department. ${ }^{495}$

Consequently, the Indiana Tax Court determined that the Indiana Bad Debt Statute does not exclude market discount income from the calculation of Indiana's bad debt deduction. ${ }^{496}$ Thus, the Department erred in denying thirty percent of SAC's three refund claims because the calculation of an Indiana bad debt deduction does not require the exclusion of market discount income. ${ }^{497}$ Accordingly, the Indiana Tax Court granted summary judgment in favor of SAC and against the Department. ${ }^{498}$

5. Garwood v. Indiana Department of State Revenue. ${ }^{499}$ - The following facts were not in dispute. ${ }^{500}$ On June 2, 2009, the Indiana Department of State Revenue served Garwood with several jeopardy tax assessments which provided that Garwood owed approximately $\$ 125,000$ in sales tax, penalties, and interest on Garwood's sales of dogs. ${ }^{501}$ When Garwood indicated that she could not pay the liability, the Department seized 240 of her dogs pursuant to several jeopardy tax warrants. ${ }^{502}$ The Department also seized \$1260 in cash and \$1325 in

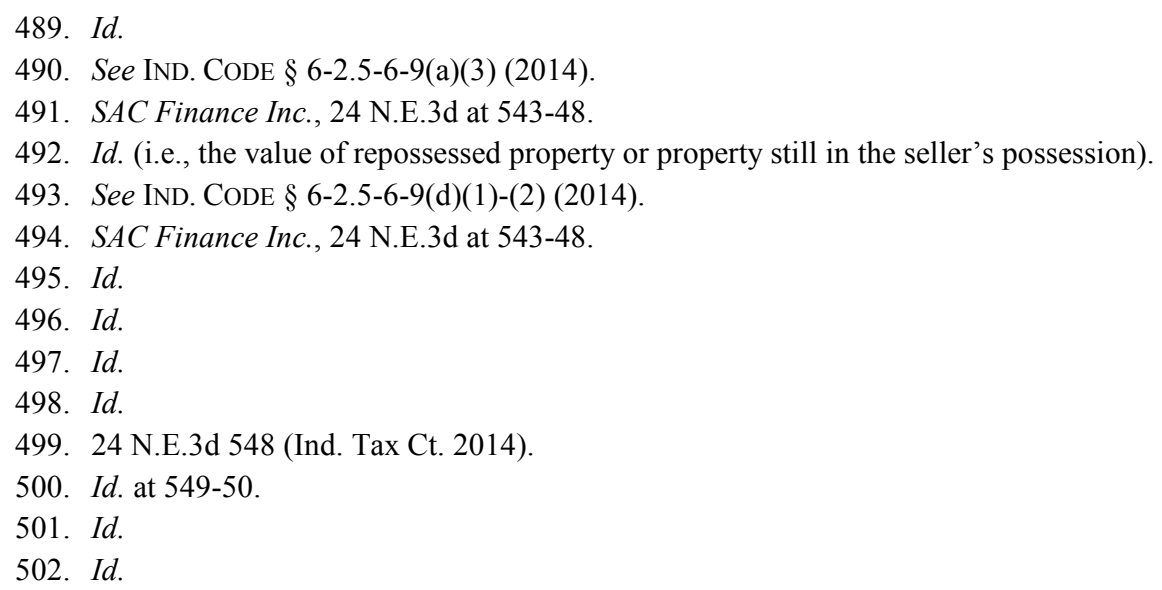


uncashed checks. ${ }^{503}$

Thereafter, the Department contended that it was entitled to judgment as a matter of law, because the Department had already "returned all [of the] monies [that] it obtained from Garwood, [and therefore] there [was] nothing else left for [her] to receive from the Department." ${ }^{504}$ The Department stated that a tax payment through Indiana Code section 6-8.1-8-14 cannot be made by providing goods ${ }^{505}$ or services to the Department and that Garwood was actually "seek[ing] compensatory damages ... when she asks for more money than she paid in tax. ${ }^{, 506}$

However, the Indiana Tax Court agreed that Garwood's claim for damages, arising from its sale of her animal inventory, should be litigated. ${ }^{507}$ Thus, even if the Indiana Tax Court determined that the provision of goods or services did not constitute a tax payment through Indiana Code section 6-8.1-8-1, the Department would not be entitled to an entry of summary judgment because Garwood had presented a claim for which the Indiana Tax Court can provide relief. ${ }^{508}$ As such, Garwood's claim for compensatory damages would be heard in the Indiana Tax Court without a jury. ${ }^{509}$ Accordingly, the Indiana Tax Court denied the Department's motion for summary judgment. ${ }^{510}$

D. Corporate Income Tax: Medco Health Solutions, Inc. v. Indiana Department of State Revenue ${ }^{511}$

Medco is a Delaware corporation with its headquarters and principal place of business in New Jersey. ${ }^{512}$ As a result of a 2007 audit, the Indiana Department of State Revenue determined that Medco had not sourced income properly according through the Indiana sales factor. ${ }^{513}$ Therefore, a recalculated amount was made and that resulted in Medco owing additional Indiana adjusted gross income tax. ${ }^{514}$ Medco timely protested the proposed assessments and the Department held a hearing with respect to Medco's protest. ${ }^{515}$ On March 7, 2011, the Department issued a Letter of Findings denying Medco's protest and on May 5, 2011, Medco initiated an original tax appeal ${ }^{516}$.

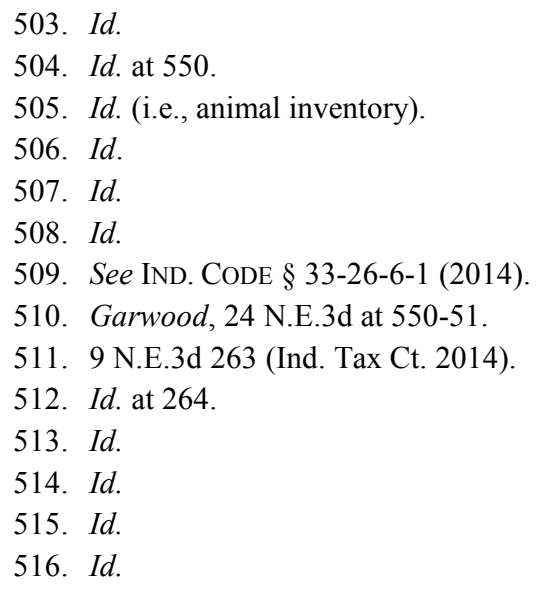


On appeal, the Department argued that the two claims made by Medco must be dismissed per Trial Rule 12(B)(6), because the claims could not be provide legal relief. ${ }^{517}$ The Indiana Tax Court agreed and determined that Medco was not entitled to relief because a claim for refund was never initiated. ${ }^{518}$ Accordingly, the Indiana Tax Court held that a final determination addressing only the taxpayer's protest of proposed assessments would not constitute a denial of a claim for refund. ${ }^{519}$

\section{E. Tax Procedure}

1. Popovich v. Indiana Department of State Revenue. ${ }^{520}$ - In 2007, the Indiana Department of State Revenue audited Popovich for the 2002 through 2004 tax years. ${ }^{521}$ At the conclusion of the audit, the Department issued an investigation summary to Popovich explaining that because Popovich was not a professional gambler, he was not entitled to certain business expense deductions. ${ }^{522}$ Accordingly, the Department issued proposed assessments to Popovich for additional income tax, interest, and penalties ${ }^{523}$ Popovich protested the Department's proposed assessments and on August 3, 2010, the Department issued a Letter of Findings which upheld each of the proposed assessments. ${ }^{524}$ Then, on October 4, 2010, Popovich appealed to the Indiana Tax Court. ${ }^{525}$

Popovich served the Department with his first set of discovery requests, which consisted of nineteen requests for admission, forty-three separately numbered interrogatories, and twenty-one separately numbered requests for production. ${ }^{526}$ In response, the Department objected to providing the information sought in thirty-eight of the forty-three interrogatories and fifteen of the twentyone requests for production, because of the protections provided with respect to confidential information through Ind. Code section 6-8.1-7-1 or the protections from disclosure by the work-product, attorney-client, and deliberative process privileges. ${ }^{527}$

Thereafter, the Indiana Tax Court, by moving to compel discovery through Indiana Rules of Trial Procedure 37(A), determined that the documents sought were relevant and discoverable through 26(B)(1), because the documents were related to issues in the case and because the discovery requests did not lack

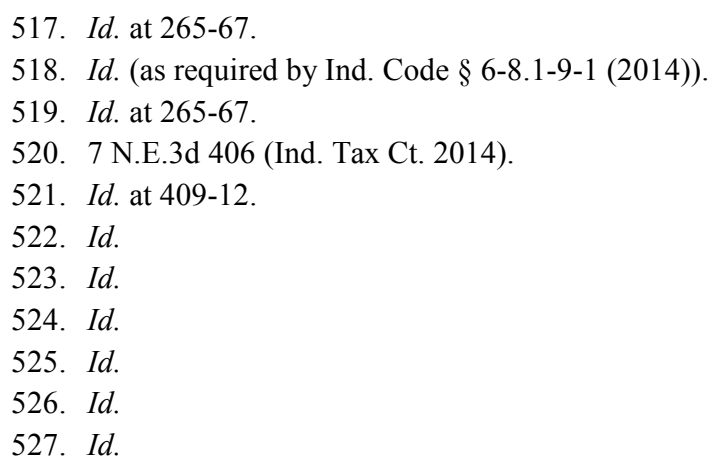


relevance. ${ }^{528}$ Moreover, the Indiana Tax Court determined that Indiana's case law did not recognize a deliberative process privilege for purposes of discovery and that Ind. Code section 5-14-3-4(b)(6) was inapplicable because no public records request was involved. ${ }^{529}$

Therefore, the Indiana Tax Court granted Popovich's Motion to Compel, with the exception, and because of the general bar against probing the mental processes and deliberations of Interrogatory Number 4, the Indiana Tax Court denied the Department's Motion for Protective Order, with the exception of Interrogatory Number $4 .{ }^{530}$ In addition, the Department was required to fully respond to Popovich's discovery requests and identify the work-product and attorney-client privilege objections with respect to Interrogatory Number 4 with the particularity contemplated by Trial Rule 26(B)(5) within forty-five days. ${ }^{531}$

2. Popovich v. Indiana Department of State Revenue. ${ }^{532}$-The Department advised Popovich in an email that the Department would not permit the removal of the original documents from its offices because that request exceeded the requirements of Trial Rule $34 .{ }^{533}$ Furthermore, the Department stated Popovich could inspect the original documents at its offices and that its witness would bring true and accurate copies of the documents for use at the deposition. ${ }^{534}$ That same afternoon, Popovich replied to the Department arguing that he believed the request was consistent with Indiana's Trial Rules, but as an accommodation, he would limit his request to twenty-seven pages of original documentation and accept copies of the other requested documents. ${ }^{535}$ Popovich also stated that if the Department did not produce the original documents as requested, he would file a motion to compel. ${ }^{536}$

Ultimately, the Indiana Tax Court denied Popovich's second motion to compel because the expectation that the movant will make a reasonable effort to resolve discovery disputes with the opposing party before moving to enforce, modify, or limit discovery holds true. ${ }^{537}$ Therefore, the Indiana Tax Court held that motion to compel discovery of documents for use at a deposition pursuant to Indiana Rules of Trial Procedure 37(A) failed to comply with the requirements because the motion did not document informal attempts to resolve the discovery dispute. $^{538}$

Additionally, the Indiana Tax Court determined that although the motion described sending an email that modified the number of original documents

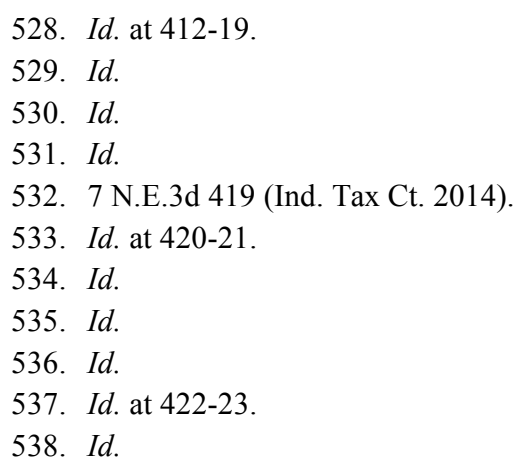


requested, this was insufficient to qualify as an attempt to resolve the dispute because there was no indication that a back and forth exchange had occurred or that the parties had engaged in any discussion to resolve the impasse after the deposition adjourned, even though an original document that was material to one of the claims had been produced immediately thereafter. ${ }^{539}$

3. Popovich v. Indiana Department of State Revenue. ${ }^{540}$ - The Indiana Tax Court held that the Indiana Tax Court did not err in the previous finding that Popovich was required to comply with Indiana Rules of Trial Procedure 26(F) ("Rule 26(F)"), because Popovich's statements in his motion brought him within the ambit of Indiana Rules of Trial Procedure 37, and therefore, required compliance with Rule 26(F). ${ }^{541}$ Popovich's failure to comply with Rule 26(F) was not cancelled by the purported bad behavior of Popovich, and thus, was not excusable. ${ }^{542}$

On April 24, 2014, the Indiana Tax Court denied Popovich's second motion to compel, because Popovich did not comply with the requirements of Rule 26(F). ${ }^{543}$ Popovich then asked the Indiana Tax Court, to reconsider its holding in Popovich II. ${ }^{544}$ In addition, the Indiana Tax Court reaffirmed the decision. ${ }^{545}$

Popovich advanced two reasons for such a decision. First, Popovich claimed the Indiana Tax Court erred in concluding that he needed to comply with Rule 26(F), and in addition, Popovich argued that even if he were required to do so, the Indiana Tax Court should have excused his failure to comply. ${ }^{546}$

Thereafter, the Indiana Tax Court held that no error had occurred in previously finding that petitioner was required to comply with Rule 26(F), because the petitioner's language in his motion brought him within the ambit of Indiana Rules of Trial Procedure 37, and therefore, required compliance with Rule 26(F). ${ }^{547}$ Moreover, Petitioner's failure to comply with Rule 26(F) was not cancelled by the purported bad behavior of respondent, and thus was not excusable. ${ }^{548}$

Popovich explained that he issued a subpoena pursuant to Indiana Trial Rule 45, which required the Department's witness to appear for the deposition with certain original documentation. ${ }^{54}$ Therefore, because the second motion to compel concerned the witness's compliance with Trial Rule 45, no duty to comply with Rule $26(\mathrm{~F})$ existed. ${ }^{550}$ Nevertheless, the argument was not

539. Id.

540. 13 N.E.3d 954 (Ind. Tax Ct. 2014).

541. Id.

542. Id.

543. See generally Popovich v. Ind. Dep't of State Revenue, 7 N.E.3d 419 (Ind. Tax Ct. 2014).

544. Popovich, 13 N.E.3d 954.

545. Id.

546. Id.

547. Id.

548. Id.

549. Id.

550. Id. 
persuasive and the Indiana Tax Court determined an error had not occurred. ${ }^{551}$ Furthermore, the petitioner's failure to comply with Rule 26(F) was never cancelled by purported bad behavior of respondent, and Popovich's own language in his second motion to compel brings him within the ambit of Indiana Rules of Trial Procedure 37..$^{52}$

4. Popovich v. Indiana Department of State Revenue. ${ }^{553}$ - This matter concerned Popovich's motion for default judgment, costs, and attorney's fees as sanctions for the Indiana Department of State Revenue's purported spoliation of evidence and discovery abuses. ${ }^{554}$ The Indiana Tax Court denied the motion, and thereafter, Popovich filed a motion for Trial Rule 37 sanctions, including judgment and fees, requesting an entry of default judgment and an award of all litigation costs, claiming that the Department had purposefully destroyed, mutilated, or lost his 2003 transmittal envelope and obstructed discovery. ${ }^{555}$ Popovich made two arguments. ${ }^{556}$ First, Popovich claimed that the Department should be sanctioned for spoliation of evidence. ${ }^{557}$ Second, in the alternative, Popovich claimed the severity of the discovery abuses, as well as the misrepresentations regarding the 2003 transmittal envelope, warranted the imposition of sanctions. ${ }^{558}$

However, neither the Department's retention schedule nor the Indiana Code expressly refer to the retention of a tax return transmittal envelope or define the term "tax return." ${ }^{559}$ Consequently, the Indiana Tax Court defined the term "tax return" consistent with its plain, ordinary, and usual meaning. ${ }^{560}$ Accordingly, Popovich did not show that the Department had a statutory duty to preserve his 2003 transmittal envelope. ${ }^{561}$

551. Id.

552. Id.

553. 17 N.E.3d 405 (Ind. Tax Ct. 2014).

554. Id. at 407 .

555. Id.

556. Id.

557. Id. at $411-18$.

558. Id.

559. See also InD. CoDE $\S 6-8.1-3-6$ (2014).

560. See Johnson Cnty. Farm Bureau Coop. Ass'n v. Ind. Dep't of State Revenue, 568 N.E.2d 578, 581 (Ind. Tax Ct. 1991).

561. Popovich, 17 N.E.3d at 411-18. 
